\title{
Three new gonad-infecting species of Philometra (Nematoda: Philometridae) parasitic in Lutjanus spp. (Lutjanidae) in the northern Gulf of Mexico off Florida, USA
}

\author{
František Moravec $^{1}$, Micah Bakenhaster ${ }^{2}$ and Emma J. Fajer-Ávila ${ }^{3}$ \\ ${ }^{1}$ Institute of Parasitology, Biology Centre of the Academy of Sciences of the Czech Republic, České Budějovice, Czech Republic; \\ ${ }^{2}$ Fish and Wildlife Research Institute, Florida Fish and Wildlife Conservation Commission, St. Petersburg, Florida, USA; \\ ${ }^{3}$ Centro de Investigación en Alimentación y Desarrollo, A. C., Unidad Mazatlán en Acuicultura y Manejo Ambiental, Mazatlán, \\ Sinaloa, Mexico
}

\begin{abstract}
Based on light and scanning electron microscopical studies, three new gonad-infecting species of Philometra Costa, 1845 (Nematoda: Philometridae) are described from marine fishes of the genus Lutjanus Bloch (Perciformes: Lutjanidae) in the northern Gulf of Mexico: P. longispicula sp. n. from the ovary of the northern red snapper L. campechanus (Poey) (type host) and silk snapper L. vivanus (Cuvier); P. latispicula sp. n. from the ovary and rarely testes of the grey snapper L. griseus (Linnaeus); and P. synagridis sp. n. (only males available) from the ovary of the lane snapper Lutjanus synagris (Linnaeus). These species are mainly characterised by the lengths of spicules (378-690 $\mu \mathrm{m}, 135-144 \mu \mathrm{m}$ and 186-219 $\mu \mathrm{m}$, respectively) and spicule shapes, structure of the distal portion of the gubernaculum and the structure of the male caudal end. These are the first valid, nominal species of gonadinfecting philometrids reported from fishes of the family Lutjanidae in the western Atlantic region.
\end{abstract}

Keywords: Dracunculoidea, parasitic nematode, fish parasites, marine fishes, taxonomy

During recent helminthological examinations of snappers (Lutjanidae) from the West Florida Shelf in the northern Gulf of Mexico, three previously undescribed gonad-infecting species of Philometra Costa, 1845 (Nematoda) were collected from the northern red snapper Lutjanus campechanus (Poey), gray snapper L. griseus (Linnaeus), lane snapper L. synagris (Linnaeus) and silk snapper $L$. vivanus (Cuvier) (Lutjanidae). These are described herein. All the aforementioned host species are subtropical marine fishes that are widespread in the western Atlantic and are targeted by commercial and recreational fisheries (Froese and Pauly 2014).

\section{MATERIALS AND METHODS}

Host specimens were selected asystematically from among those that were captured by the Florida Fish and Wildlife Conservation Commission's (FWC) Fish and Wildlife Research Institute (FWRI) from June 2011 to August 2013 as part of routine fisheries independent monitoring surveys or targeted collections. These samples were supplemented with those we opportunely collected from discarded carcasses while we provided shipboard support for an unrelated health survey conducted by the University of South Florida (USF) during July 2011. Some additional specimens of $L$. campechanus were captured in June 2010 by recreational fishers onboard charter vessels participat- ing in FWRI disease survey off Panama City, Florida. Fish were captured with seine nets, hook and line, spear guns, fish traps, or longline tackle. Charter vessel captains targeted reefs known to be productive for hook and line fishing and did not provide precise GPS coordinates. Otherwise sampling stations (Fig. 1) were selected by three basic means; 1) stratified random sampling design (FWRI fisheries independent monitoring surveys), 2) bathymetrically defined points at approximately $18 \mathrm{~m}, 36 \mathrm{~m}$, $73 \mathrm{~m}$ and $146 \mathrm{~m}$ isobaths along north-south transects off the Florida Panhandle (USF samples), or 3) deliberate selection of sites in the Tampa Bay region where spearfishing was likely to be successful. All hosts were measured for standard length (SL).

Methods of collection of nematodes and checks for presence and absence of infection varied greatly as a factor of logistic necessity and opportunity. Hosts or extracted gonads were placed on ice immediately after collection, but the time on ice varied from less than an hour to about 48 hours before processing. When trained workers were onboard sampling vessels (FWRI cruises in part and USF cruise), we determined presence or absence of worms in the field solely by gross examination of whole gonads and we retained parasitological samples only from hosts with visible infections. In cases when no trained parasitologist was onboard an offshore sampling vessel (FWRI cruises in part and charter vessel samples) and for all inshore sampling, whole iced fish were returned to the laboratory for evaluation either at FWRI (Saint Petersburg, USA) or FWC Northwest Regional Office (Panama City, FL, USA). At a minimum, we grossly ex- 


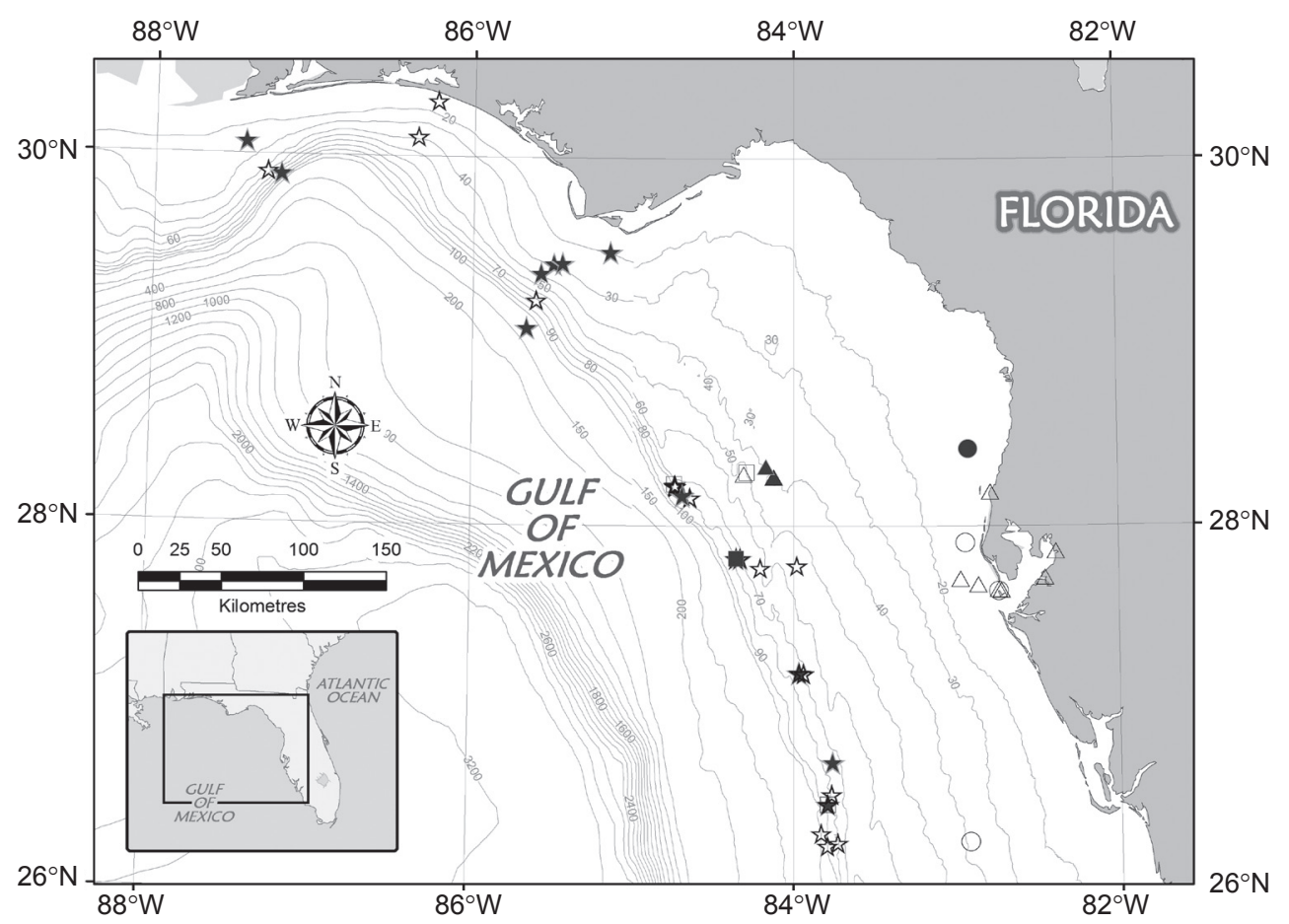

Fig. 1. Map of study area identifying sampling stations where the parasitic nematodes Philometra longispicula sp. n., P. latispicula sp. n. and P. synagridis sp. n. were present (solid symbols) or absent (empty symbols) in their hosts Lutjanus campechanus (stars) and L. vivanus (squares), L. griseus (triangles) and L. synagris (circles), respectively.

amined gonads in the laboratory to score for infection. In some cases we evaluated gonads that were not obviously infected (some representative female hosts and all males) by vigorously agetating (ovaries) or tearing apart and smashing by hand (testes), then flushing gonadal tissue with saline to check for the presence of minute males or juvenile females under a Leica M125 stereomicroscope (Leica Microsystems, Herbrug, Switzerland) equipped with a polarizer. Rarely, nematodes were fixed with $10 \%$ buffered formalin solution in situ with gonad tissue prior to isolation. Whether in the field or laboratory, we extracted visible nematodes with a combination of fine paint brushes, forceps and saline rinse.

Nematode specimens to be used for morphological evaluation were isolated and rinsed with saline and then, with a few exceptions, killed with hot $\left(70-80^{\circ} \mathrm{C}\right)$ tap water before fixation in $5 \%$ buffered formalin solution. To informally investigate whether isolated female nematodes might be less likely to rupture with different fixation methods (they were not), we fixed a few specimens in $10 \%$ buffered formalin solution with and without first killing them with hot water. While numerous infections by minute, mature females and males were detected, and while these specimens were used for morphological descriptions, here we reported prevalence and intensity data only for macroscopically visible infections except in the case of L. synagris, for which no macroscopically visible infections were detected. Similarly, although some host gonads contained granulomatous masses indicative of recent infection by philometrids (see Bakenhaster et al. 2014), these were considered uninfected unless they also contained live, macroscopically visible worms.

For light microscopy, nematodes were cleared with glycerine. Drawings were made with the aid of a Zeiss drawing at- tachment (Carl Zeiss, Jena, Germany). After examination, the specimens were stored in vials with $70 \%$ ethanol. Specimens examined via scanning electron microscopy were postfixed in $1 \%$ osmium tetroxide (in phosphate buffer), dehydrated through a graded acetone series, critical-point-dried and sputter-coated with gold; they were examined using a JEOL JSM-7401F scanning electron microscope at an accelerating voltage of $4 \mathrm{kV}$ (GB low mode). All measurements are in micrometres unless otherwise indicated. The names of fishes follow FishBase (Froese and Pauly 2014).

\section{RESULTS}

Philometra longispicula sp. $\mathrm{n}$.

Figs. 2-4

Male (17 specimens from Lutjanus campechanus; measurements of holotype in parentheses. Measurements of 2 specimens from L. vivanus in square brackets): Body whitish, filiform, slender, 3.61-4.68 (4.19) [3.02] mm long, maximum width at middle 54-66 (57) [48-51]; anterior part of body somewhat constricted just posterior to cephalic end (Fig. 2A); body width at this constriction 27-33 (30) [24-27]. Maximum width/body length $1:$ 64-73 (1:73) [1:59-63]; width of cephalic end 30-36 (36) [27-30], that of posterior end 30-45 (33) [30-33]. Cuticle smooth. Cephalic end rounded.

Oral aperture small, circular, surrounded by 14 cephalic papillae arranged in 2 circles: outer circle formed by 4 submedian pairs of papillae; inner circle by 4 submedian and 2 lateral papillae (Figs. 2B, 4B). Small lateral amphids 
A

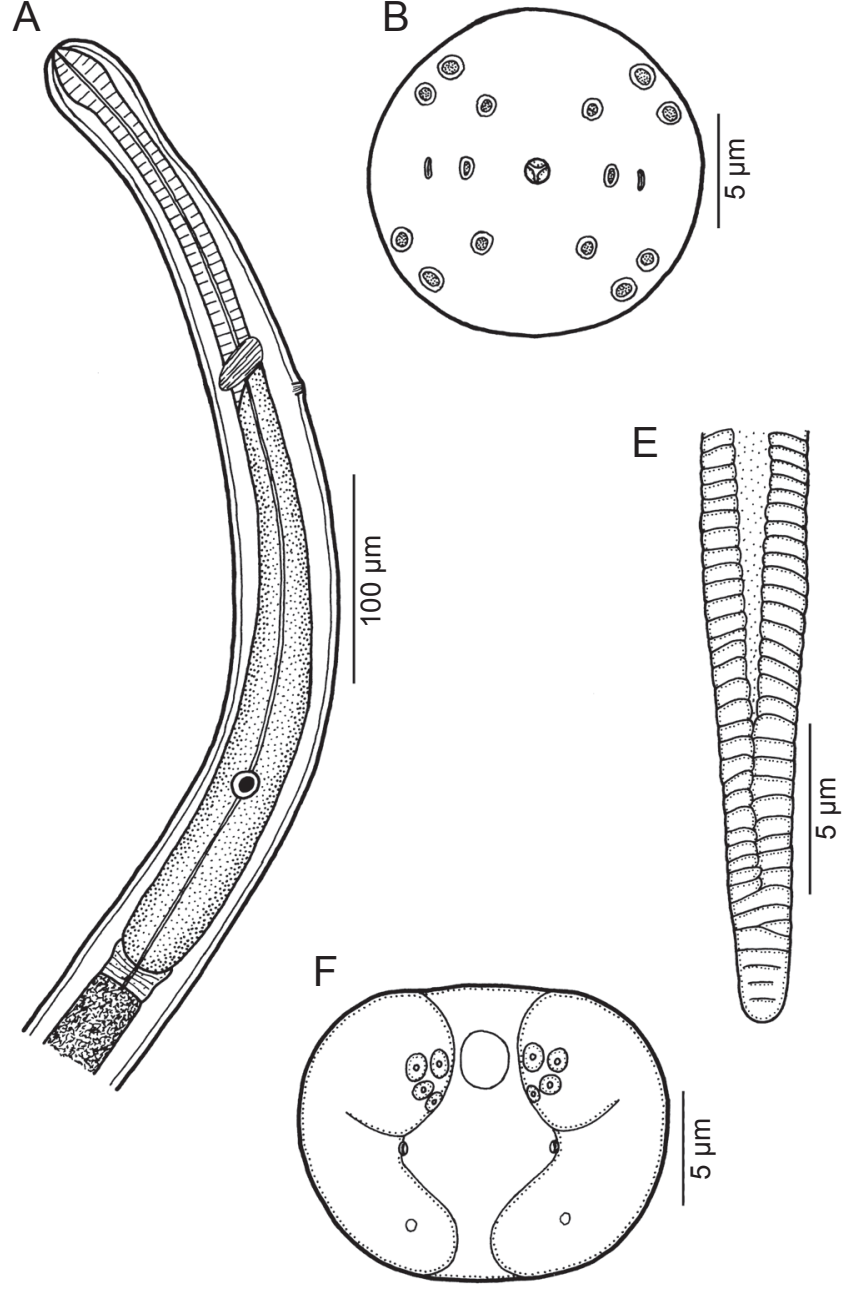

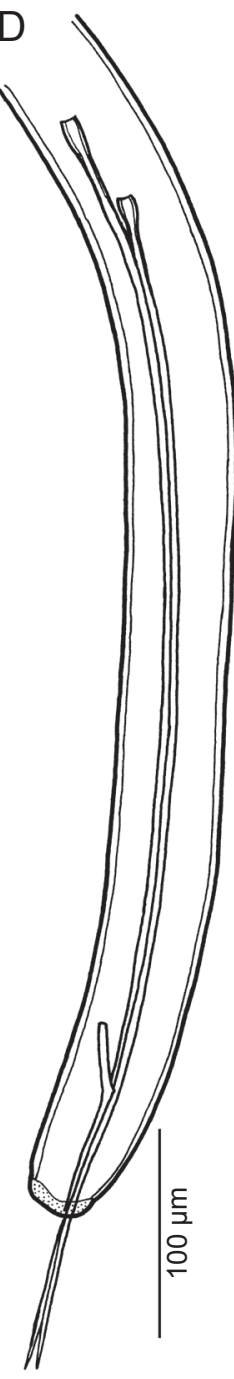

Fig. 2. Male of Philometra longispicula sp. n. from Lutjanus campechanus. A - anterior end, lateral view; B - cephalic end, apical view; C, D - posterior end (different magnifications), lateral views; $\mathbf{E}$ - distal part of gubernaculum, dorsal view; $\mathbf{F}, \mathbf{G}-$ caudal end, apical and ventral views.

just posterior to lateral papillae of inner circle (Figs. 2B, 4B). Oesophagus 474-642 (633) [414-480] long, maximum width 27-33 (27) [21-27], comprising 10-16 (15) $[14-16] \%$ of body length, slightly inflated at anterior end; posterior part of muscular oesophagus overlapped by well-developed oesophageal gland with large cell nucleus situated somewhat posterior to its middle (Fig. 2A); anterior oesophageal inflation 24-45 (39) [27-33] long and 12-24 (24) [18-21] wide. Oesophageal nucleus, nerve ring and excretory pore 366-540 (513) [321-399], 180-216 (216) [186-189] and 213-285 (267) [213-216], respectively, from anterior extremity (Fig. 2A).

Testis not reaching anteriorly to oesophagus. Posterior end of body blunt, with 2 broad, reniform caudal mounds well separated dorsally (Figs. 2F, 4C-E). Caudal papillae small, very flat, difficult to observe, forming 2 groups of 4 papillae each on sides of cloacal aperture (Figs. 2F, 4C-E). Pair ogsmall phasmids situated in middle of inner border of each lateral caudal mound (Figs. 2F, 4D,E). Dorsal portion of each caudal mound with 1 minute depression (Figs. 2F, 4C,D). Spicules slender, needle-like, unequally long, with tips somewhat expanded proximally and sharply pointed at distal apices (Figs. 2C,D, G, 4C-E); right and left spicule 597-690 (624) [459-519] and 510-618 (567) [378-459] long, respectively; larger (right) spicule comprising 13-19 (15) [15-17]\% of body length. Length ratio of spicules $1: 1.07-1.35(1: 1.10)$ [1:1.13-1.21].

Gubernaculum narrow, 99-129 (108) [102] long, with anterior portion somewhat bent dorsally. Length of bent part 27-33 (33) [24-27], representing 22-33 (31) $[24-26] \%$ of entire gubernaculum length. Each dorsolateral margin of distal gubernaculum with row of transverse lamella-like structures; these rows joined and fused well anterior to gubernaculum apex but proximally separated by smooth depressed field. Distal ventral surface of gubernaculum with 2 conspicuous longitudinal 


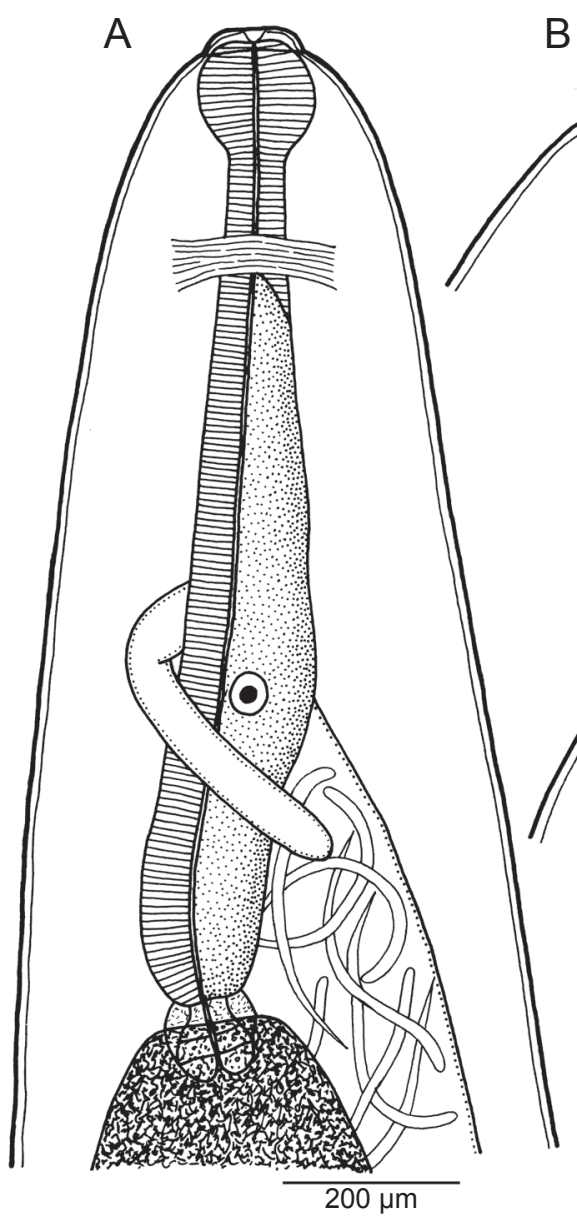

B
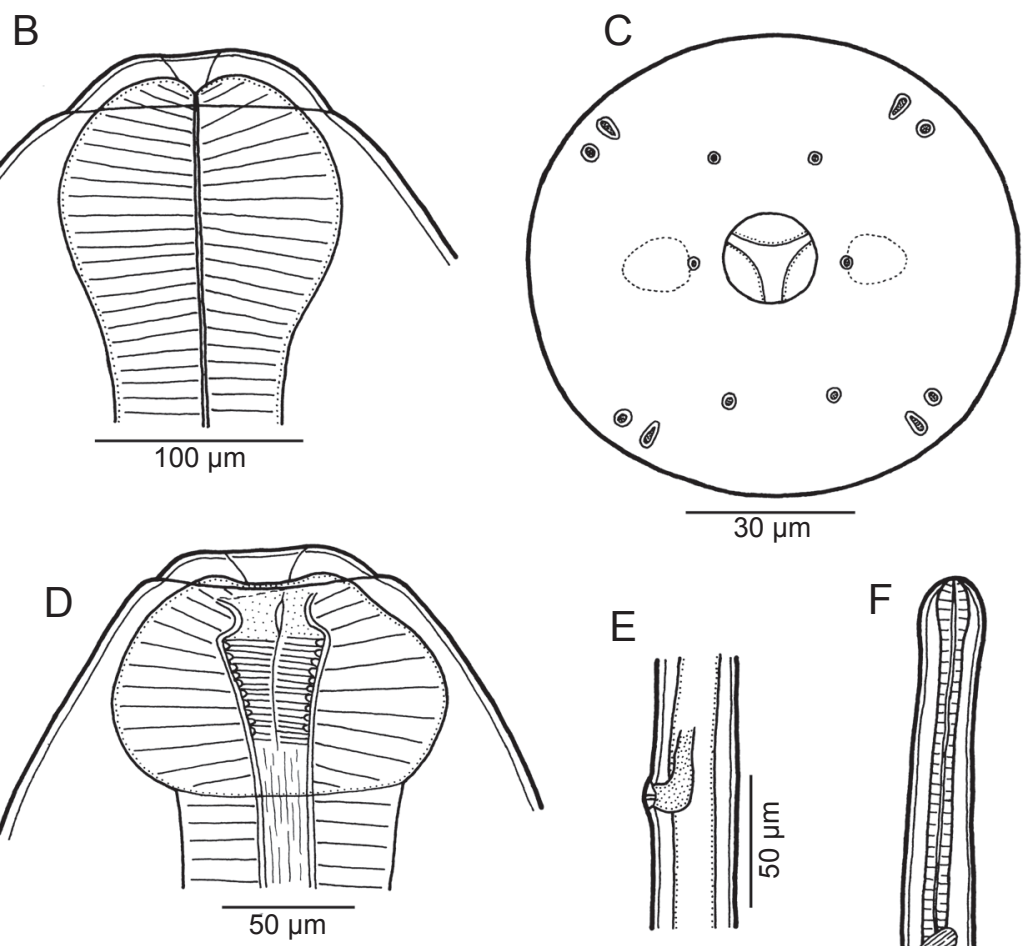

$\mathrm{E}$
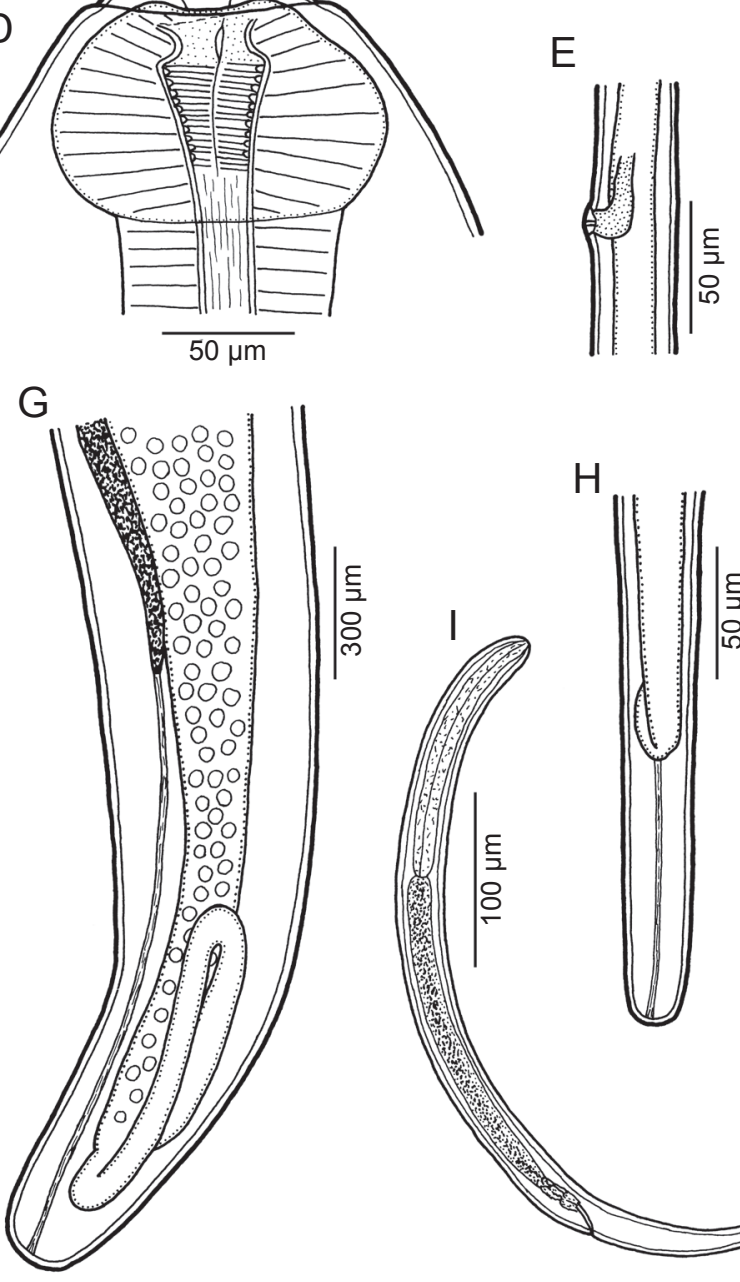

F

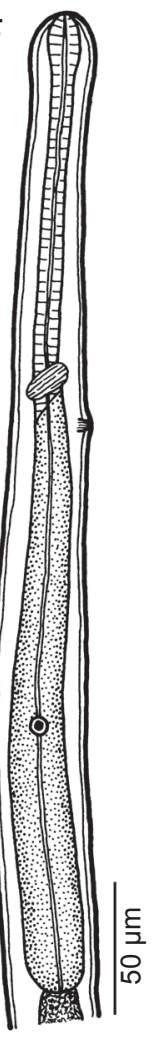

$\mathrm{K}$
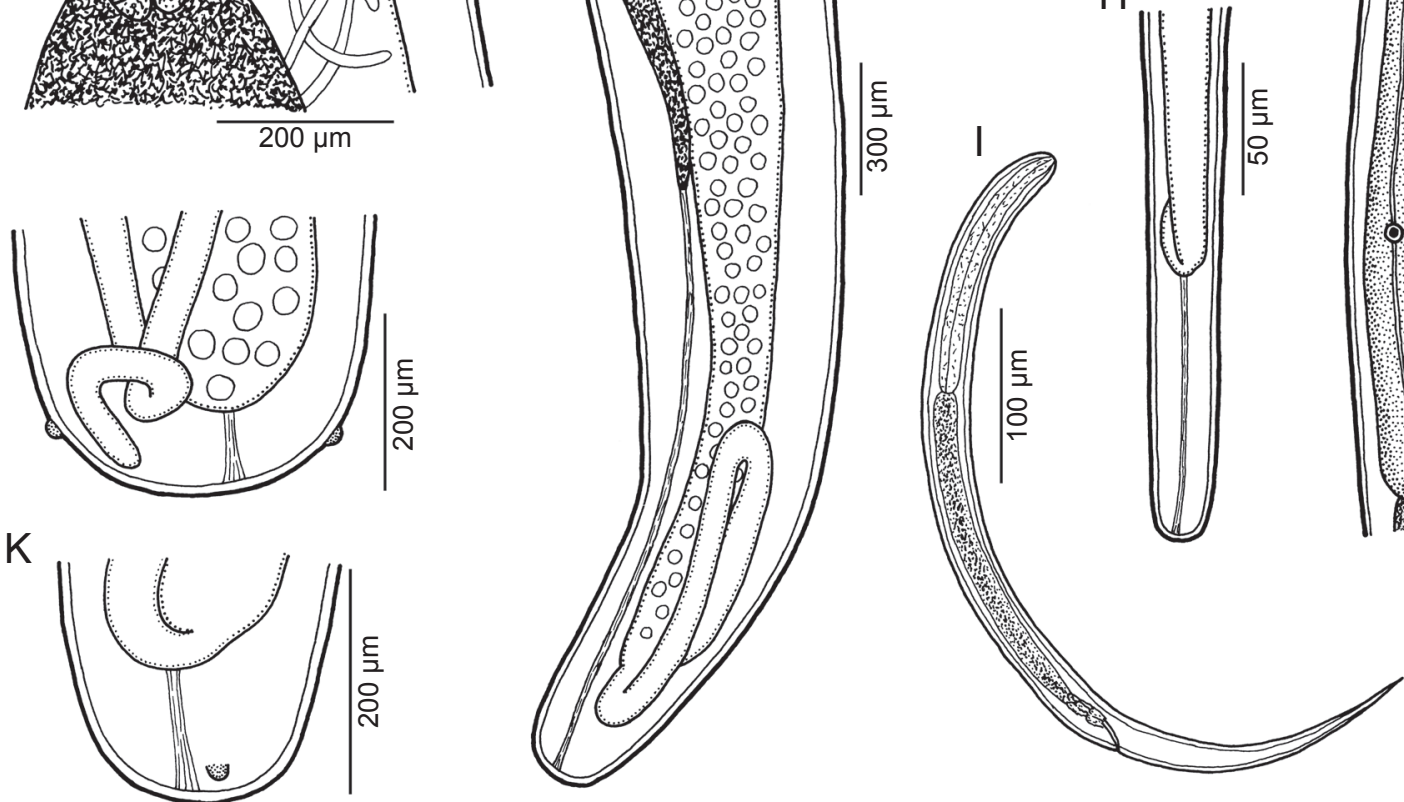

Fig. 3. Female of Philometra longispicula sp. n. from Lutjanus campechanus. A - anterior end of gravid female, lateral view; B, $\mathbf{C}$ - cephalic end of gravid female, lateral and apical views; $\mathbf{D}$ - cephalic end of fragmented gravid female with distinct buccal cavity ringed with transverse striae, lateral view; $\mathbf{E}$ - vulva of mature female, lateral view; $\mathbf{F}$ - anterior end of mature female, lateral view; $\mathbf{G}$ - posterior end of gravid female, lateral view; $\mathbf{H}$ - posterior end of mature female, lateral view; $\mathbf{I}$ - larva from uterus, lateral view; $\mathbf{J}, \mathbf{K}$ - caudal end of gravid female, dorsoventral and lateral views.

grooves (Figs. 2C-E, 4C-F). Length ratio of gubernaculum and longer (right) spicule $1: 4.70-6.90(1: 5.78)$ $[1: 4.50-5.09]$. Spicules and gubernaculum well sclerotised; yellowish, except colourless anterior part of gubernaculum.
Gravid female ( 9 complete and 8 incomplete larvigerous specimens; measurements of allotype in parentheses): Body of fixed specimen brown, with distinct dark-brown intestine visible through cuticle; body ends rounded. Posterior part of body narrower than anterior part; maxi- 
mum width in region just posterior to oesophagus. Cuticle smooth. Body length 130-250 (210) mm, maximum width 680-1265 (680), maximum width/body length ratio $1: 130-309(1: 309)$. Width of cephalic end 150-381 (150). Mouth region usually separated from rest of body by distinct groove (Figs. 3A,B,D, 4A). Cephalic papillae small, indistinct when viewed laterally.

Oral aperture circular, surrounded by small cephalic papillae arranged in 2 circles and slightly outlines amphids; inner circle of papillae consisting of 4 submedian and 2 lateral single papillae, outer circle formed by 4 submedian pairs of papillae, each pair composed of 1 short and 1 elongate papilla (Figs. 3C, 4A). Oesophagus including well-developed anterior bulbous inflation $1.09-1.56$ (1.21) mm long, comprising 0.6-1.2 (0.6)\% of body length; anterior inflation 109-163 (122) long and 136-163 (150) wide; maximum width of posterior part of oesophagus including gland 136-177 (177).

Buccal cavity in ruptured specimens broad, inner surface ringed with numerous transverse striae (Fig. 3D). Oesophageal gland well developed, opening into oesophagus just posterior to nerve ring, with large cell nucleus (Fig. 3A). Nerve ring and oesophageal nucleus 245-408 (313) and 612-911 (748), respectively, from anterior extremity. Ventriculus small, 27-54 (41) long, 82-136 (95) wide. Posterior end of intestine attached by relatively long ligament ventral to body wall near caudal end (Fig. 3G); length of ligament 0.70-2.11 (1.25) mm. Vulva and anus absent.

Ovaries reflexed near body ends (Fig. 3A,G). Uterus occupying most space of body, filled with numerous larvae (Fig. 3A,I). Larvae $(\mathrm{n}=10)$ 489-765 (489-627) long and 18 (18) wide; oesophagus 153-174 (153-174) long, comprising 22-47 (28-47)\% of body length; length of sharply pointed tail 165-192 (174-192), comprising $22-53(30-53) \%$ of body length (Fig. 3I). Posterior end of female rounded, 190-326 (286) wide, with 2 small lateral papilla-like caudal projections (Fig. 3J,K); projections indistinct in some specimens.

Subgravid female (2 ovigerous specimens): Body length 92-102 mm, maximum width 639-1088; maximum width/length ratio $1: 94-144$. Oesophagus including anterior bulbous inflation 1.13-1.43 $\mathrm{mm}$ long, comprising $1.2-1.4 \%$ of body length; anterior inflation $122-150$ long, 136-163 wide; maximum width of posterior part of oesophagus including gland 122-163. Nerve ring and oesophageal nucleus $258-408$ and $726-884$, respectively, from anterior extremity. Length of intestinal ligament 979-986. Vulva and anus atrophied. Uterus filled with spherical eggs. Posterior end rounded, 190-326 wide; caudal projections indistinct.

Nongravid female (1 mature specimen): Body length $2.54 \mathrm{~mm}$, maximum width 39 ; maximum width/length ratio $1: 65$. Width of anterior end 24 , of narrowed part just posterior to anterior end 21, of posterior end 15. Entire oesophagus 438 long and 24 wide. Nerve ring and oesophageal nucleus 126 and 180, respectively, from anterior extremity (Fig. 3F). Intestinal ligament 96 long. Vulva and incompletely developed vagina present, former situated $1.62 \mathrm{~mm}$ from anterior extremity (at $64 \%$ of body length) (Fig. 3E). Uterus empty. Caudal end rounded (Fig. 3H).

Type host: Northern red snapper Lutjanus campechanus (Poey) (Perciformes: Lutjanidae), SL 282-705 mm (mean $472 \mathrm{~mm}$ ), that of the specimen harbouring holotype $561 \mathrm{~mm}$.

Other host: Silk snapper Lutjanus vivanus (Cuvier) (Perciformes: Lutjanidae), SL $440 \mathrm{~mm}$.

Site of infection: Gonad (ovary and testis).

Type locality: Gulf of Mexico; 19 July 2011 (29²5.44'N, $\left.85^{\circ} 26.37^{\prime} \mathrm{W}\right)$.

Other 1 o c a liti e s: Gulf of Mexico; 22 June 2010 (offshore of Panama City, Florida, approximately $29^{\circ} 56^{\prime} \mathrm{N}, 85^{\circ} 45^{\prime} \mathrm{W}$ ); $13-19$ July $2011\left(29^{\circ} 53.686^{\prime} \mathrm{N}, 87^{\circ} 12.595^{\prime} \mathrm{W} ; 29^{\circ} 22.121^{\prime} \mathrm{N}\right.$, $85^{\circ} 34.417^{\prime} \mathrm{W} ; \quad 30^{\circ} 4.029^{\prime} \mathrm{N}, \quad 87^{\circ} 25.949^{\prime} \mathrm{W} ; \quad 29^{\circ} 4.302^{\prime} \mathrm{N}$, $\left.85^{\circ} 39.715^{\prime} \mathrm{W}\right)$; 16 June 2012; 9-12 July $2012\left(27^{\circ} 11.912^{\prime} \mathrm{N}\right.$, $83^{\circ} 57.930^{\prime} \mathrm{W} ; \quad 27^{\circ} 11.916^{\prime} \mathrm{N}, \quad 83^{\circ} 57.995^{\prime} \mathrm{W} ; \quad 26^{\circ} 42.702^{\prime} \mathrm{N}$, $\left.83^{\circ} 45.610^{\prime} \mathrm{W} ; 26^{\circ} 29.098^{\prime} \mathrm{N}, 83^{\circ} 47.485^{\prime} \mathrm{W}\right) ; 2$ April 2013 $\left(29^{\circ} 29.221^{\prime} \mathrm{N}, \quad 85^{\circ} 8.555^{\prime} \mathrm{W} ; \quad 29^{\circ} 25.186^{\prime} \mathrm{N}, \quad 85^{\circ} 29.602^{\prime} \mathrm{W}\right.$; $\left.27^{\circ} 49.373^{\prime} \mathrm{N}, 84^{\circ} 19.700^{\prime} \mathrm{W} ; 27^{\circ} 49.373^{\prime} \mathrm{N}, 84^{\circ} 21.186^{\prime} \mathrm{W}\right) ; 22$ May 2013 (L. vivanus) $\left(28^{\circ} 13.577^{\prime} \mathrm{N}, 84^{\circ} 44.284^{\prime} \mathrm{W}\right) ; 31$ July $2013\left(28^{\circ} 9.760^{\prime} \mathrm{N}, 84^{\circ} 41.281^{\prime} \mathrm{W}\right)$.

Prevalence and intensity: Lutjanus campechanus: $20 \%$ [21 infected out of 103 examined; female hosts $34 \%(19 / 56)$; male hosts $4 \%(2 / 46)$; juvenile host $(n=1)$ was not infected]; 1-10 (mean 4) nematode specimens. Lutjanus vivanus: no macroscopically visible infections observed, but 1 of 8 specimens of $L$. vivanus examined microscopically hosted, in its ovary, minute specimens of $P$. longispicula $\mathrm{sp} . \mathrm{n}$.

Deposition of type specimens: Holotype (male), allotype (female) and 7 paratypes (5 males, 2 females) in the U.S. National Parasite Collection, Beltsville, Maryland, USA (USNPC Nos. 107905-107908); 53 paratypes (13 males, 40 females) in the Helminthological Collection of the Institute of Parasitology, Biology Centre of the Academy of Sciences of the Czech Republic, České Budějovice (IPCAS N-1035).

Etymology: The specific name longispicula (longus = long; spicula $=$ spicule) relates to a characteristic feature of this nematode, i.e. the presence of very long spicules.

Remarks. According to Moravec and Ali (2013), 37 gonad-infecting species of Philometra are known to parasitise marine and brackish-water fishes worldwide. However, an additional eight new species, $P$. atlantica Moravec, Bakenhaster et de Buron, 2013, P. austropacifica Moravec et Justine, 2014, P. brachiri Moravec et Ali, 2014, P. hyporthodi Moravec et Bakenhaster, 2013, P. lopholatili Moravec et Bakenhaster, 2013, P. philippinensis Quiazon et Yoshinaga, 2013, P. piscaria Moravec et Justine, 2014 and P. zabidii Moravec et Diggles, 2014, have been described since (Moravec and Bakenhaster 2013, Moravec et al. 2013, Quiazon and Yoshinaga 2013, Moravec and Ali 2014, Moravec and Diggles 2014, Moravec and Justine 2014); consequently, the present number of the known species of these parasites is 49 . Of 

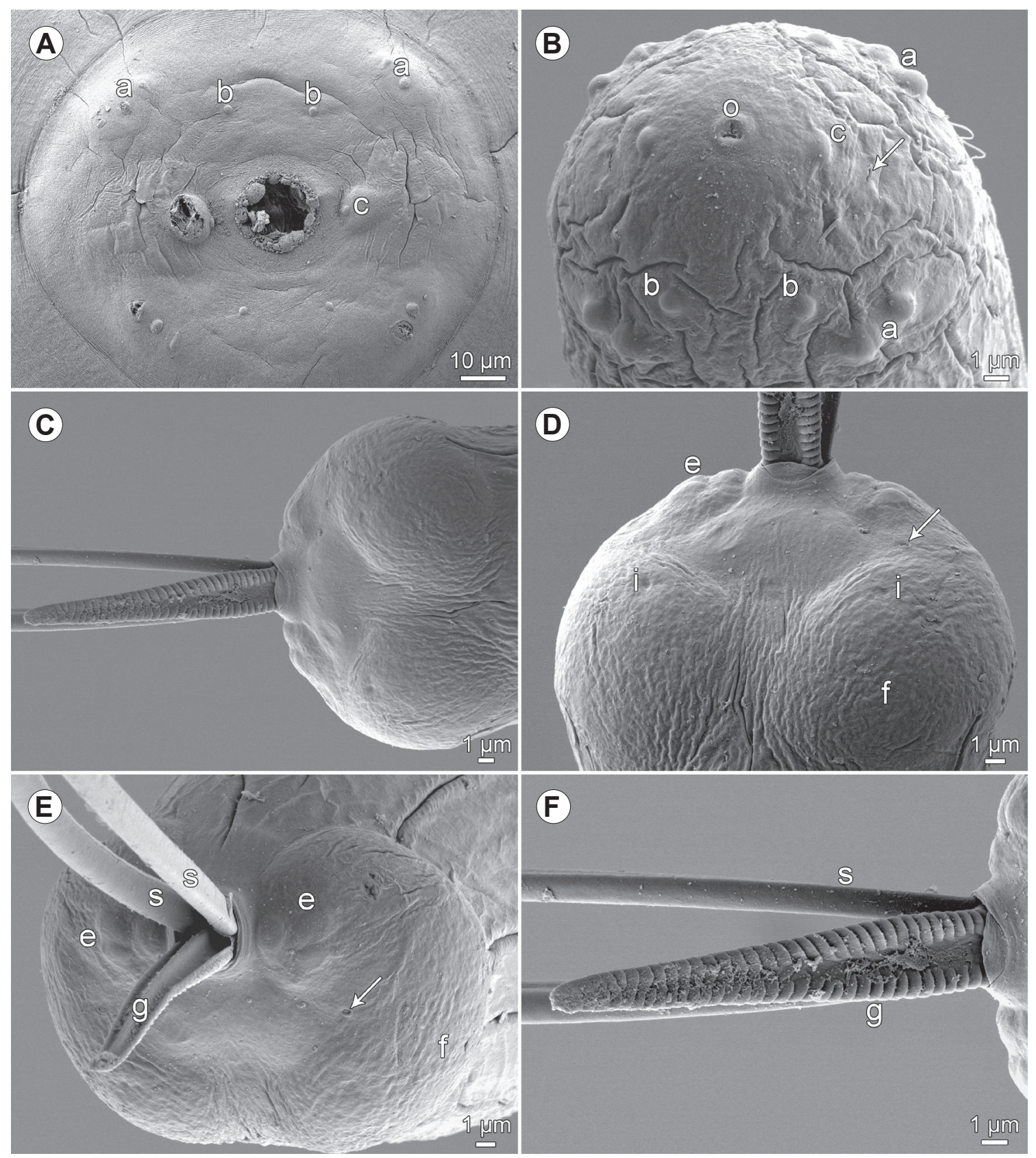

Fig. 4. Philometra longispicula sp. n. from Lutjanus campechanus, scanning electron micrographs. A - cephalic end of gravid female, apical view; B - cephalic end of male, subapical view (arrow indicates amphid); C, D - caudal end of male (different magnifications), dorsal views (arrow indicates phasmid); $\mathbf{E}$ - caudal end of male, apical view (arrow indicates phasmid); $\mathbf{F}$ - distal part of gubernaculum, dorsal view. Abbreviations: a - submedian pair of cephalic papillae of external circle; $b$ - submedian cephalic papilla of internal circle; $\mathrm{c}$ - lateral cephalic papilla of inner circle; e - group of adcloacal papillae; $\mathrm{f}$ - caudal mound; $\mathrm{g}$ - gubernaculum; $\mathrm{i}$ - minute caudal depression; $\mathrm{o}$ - oral aperture; $\mathrm{s}-$ spicule.

them, conspecific males were described for 38 species, whereas 7 species are known only by their female morphology.

The very long spicules of $P$. longispicula sp. n. are a characteristic feature of this nematode by which it easily can be distinguished from all other congeneric species with described males. Of them, only P. katsuwoni Petter et Baudin-Laurencin, 1986 from tunas in the Atlantic
Ocean, with very unequal spicules, has the right spicule longer $(1750-2570 \mu \mathrm{m} v s$ 459-690 $\mu \mathrm{m})$ but the left spicule is markedly shorter $(65-115 \mu \mathrm{m} v s 378-618 \mu \mathrm{m})$ than are those of $P$. longispicula. The body of males of P. katsuwoni is also much longer (length $8.6-17.1 \mathrm{~mm} v \mathrm{~s}$ 3.0-4.7 mm) (Petter and Baudin-Laurencin 1986, Cárdenas et al. 2009). 
By the length of spicules, the new species somewhat resembles only $P$. margolisi Moravec, Vidal-Martínez et Aguirre-Macedo, 1995, a parasite of Epinephelus morio (Valenciennes) (Serranidae) in the Gulf of Mexico (Moravec et al. 1995, 1997). However, whereas the spicules of $P$. margolisi are equally long (432-468 $\mu \mathrm{m})$, those of $P$. longispicula are markedly unequal and mostly distinctly longer (459-690 $\mu \mathrm{m}$ and 378-618 $\mu \mathrm{m})$. Moreover, gravid females of $P$. margolisi are much shorter than those of P. longispicula (65-85 $\mathrm{mm}$ vs 130-250 $\mathrm{mm}$ ), their anterior oesophageal inflation is comparatively less pronounced and their larvae are distinctly shorter (420-444 $\mu \mathrm{m} v s$ 489-765 $\mu \mathrm{m})$. Spicules of all other gonad-infecting species of Philometra are shorter than $320 \mu \mathrm{m}$.

Specimens of $P$. longispicula from $L$. vivanus were found to have slightly shorter spicules than those of males from $L$. campechanus. This is probably due to somewhat smaller body size of males from the former species, although it cannot be excluded that there may be a certain intraspecific biometrical variability in spicule lengths associated with different host species, as observed for instance in P. ovata (Zeder, 1803), a parasite of some cyprinids in Europe (Moravec 1969). In all other morphological aspects, the specimens from the two hosts were the same, so we considered them to be conspecific.

Seven valid gonad-infecting species of Philometra, P. inimici Yamaguti, 1941, P. managatuwo Yamaguti, 1941, P. neptomeni Mateo, 1972, P. otolithi Moravec et Manoharan, 2013, P. sebastisci Yamaguti, 1941, P. serranellicabrillae Janiszewska, 1949 and $P$. zabidii Moravec et Diggles, 2014 are known only from females with a rather uniform morphology. Conspecific males have not subsequently been discovered for these nominal species. However, $P$. otolithi differs from the new species mainly in having the large buccal cavity provided with many conspicuous transverse lamellae, $P$. managatuwo and $P$. serranellicabrillae in the much shorter or longer body of the gravid female (445-460 $\mathrm{mm}$ and 40-60 mm, respectively, vs 130-250 mm), P. inimici and P. sebastisci in the order of their fish hosts (Scorpaeniformes $v s$ Perciformes), and P. neptomeni and P. zabidii in the host family (Centrolophidae and Ephippidae vs Lutjanidae) and the geographical region (eastern South Pacific vs western North Atlantic).

In having a dorsal smooth field demarcated by two dorsolateral margins formed by lamellar structures on the distal portion of the gubernaculum, $P$. longispicula is similar only to $P$. brevicollis Moravec et Justine, 2011, a philometrid described from the ovary of Lutjanus vitta (Quoy et Gaimard) off New Caledonia (Moravec and Justine 2011). However, whereas the lamellar structures remain separated at the gubernaculum apex in P. brevicollis, in $P$. longispicula they meet and fuse far from the apex. Although the two species have some similar morphologi- cal features (e.g. the presence of a neck-like constriction of the anterior body wall and the arrangement of genital papillae in the male), they markedly differ in the length of spicules (279-312 $\mu \mathrm{m}$ vs 459-690 $\mu \mathrm{m})$, structure of the male caudal mound (dorsally interrupted $v s$ uninterrupted) and some other features.

\section{Philometra latispicula sp. $\mathrm{n}$.}

Figs. 5-7

Male (10 specimens; measurements of holotype in parentheses; measurements of another, less-developed specimen located in host's testis in brackets): Body filiform, whitish, 2.58-3.09 (3.09) [2.36] mm long, maximum width at middle 42-51 (48) [42]; anterior part of body with constriction just posterior to cephalic end (Figs. 5E, $6 \mathrm{~F}$ ); body width at this constriction 24-33 (33) [18]. Maximum width/body length $1: 54-67(1: 64)$ [1:56]; width of cephalic end 36-45 (42) [18], that of posterior end 33-42 (39) [27]. Cuticle smooth. Cephalic end rounded.

Oral aperture circular, surrounded by 14 cephalic papillae arranged in 2 circles: outer circle formed by 4 submedian pairs of papillae; inner circle by 4 submedian and 2 lateral papillae. Small lateral amphids just posterior to lateral papillae of inner circle (Figs. 5D,F, 6B,D). Oesophagus 381-525 (495) [495] long, forming 13-19 (16) $[21] \%$ of body length, somewhat inflated at anterior end; posterior part of muscular oesophagus overlapped by well-developed oesophageal gland 18-30 (24) [24] wide with large cell nucleus in middle. Oesophageal nucleus and nerve ring 252-434 (381) [354] and 165-210 (192) [132], respectively, from anterior extremity. Excretory pore 180-288 (225) [144] from anterior end.

Testis overlaps posterior part of oesophageal gland, usually reaching anteriorly to about oesophageal nucleus (Fig. 5E) but sometimes nearly to nerve ring. Posterior end of body blunt, provided with broad U-shaped caudal mound, this mound nearly surrounding cloacal aperture except ventrally. Four adanal pairs of very flat, hardly visible caudal papillae present on sides of cloacal aperture and pair of large papillae situated in postcloacal region demarcated by caudal mound. Small phasmids on caudal mound at level of large postcloacal papillae, posteriorly followed by pair of minute depressions (Figs. 5N, 6C, 7A-C). Spicules equal or slightly subequal in length, slender, needle-like, with ventral margin conspicuously flared between second and fourth quarter of its length. Proximal ends of spicule somewhat expanded, distal tips sharply pointed (Figs. 5J,K,M,O, 6C,E, 7C-F); length of spicules 135-144 (141/138) [117/111], representing 4-5 (5) [5]\% of body length.

Gubernaculum narrow, 117-126 (120) [75] long, with anterior portion somewhat dorsally bent; length of bent part 57-60 (57) [24], representing 48-50 (48) [32]\% of entire gubernaculum length; distal part of gubernaculum rounded, dorsal surface forming distinct longitudinal ridge of evenly spaced chevron-shaped serrations; transverse cuts of serrations angled anteriorly and extending 

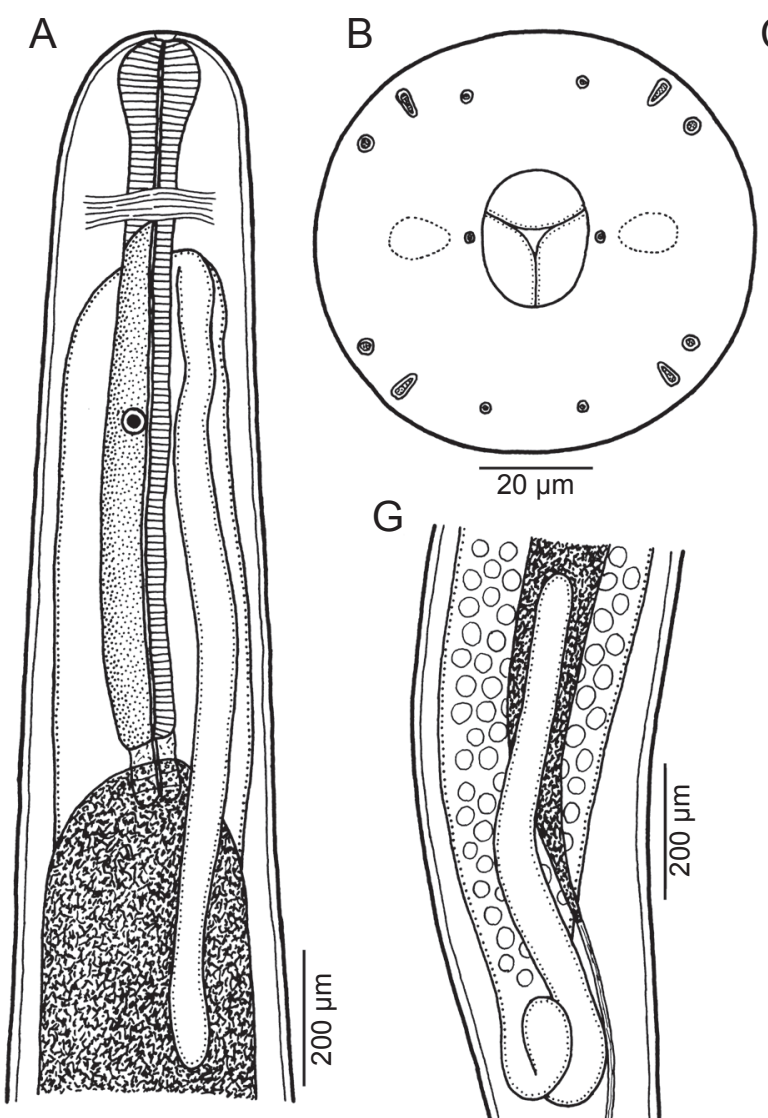

C
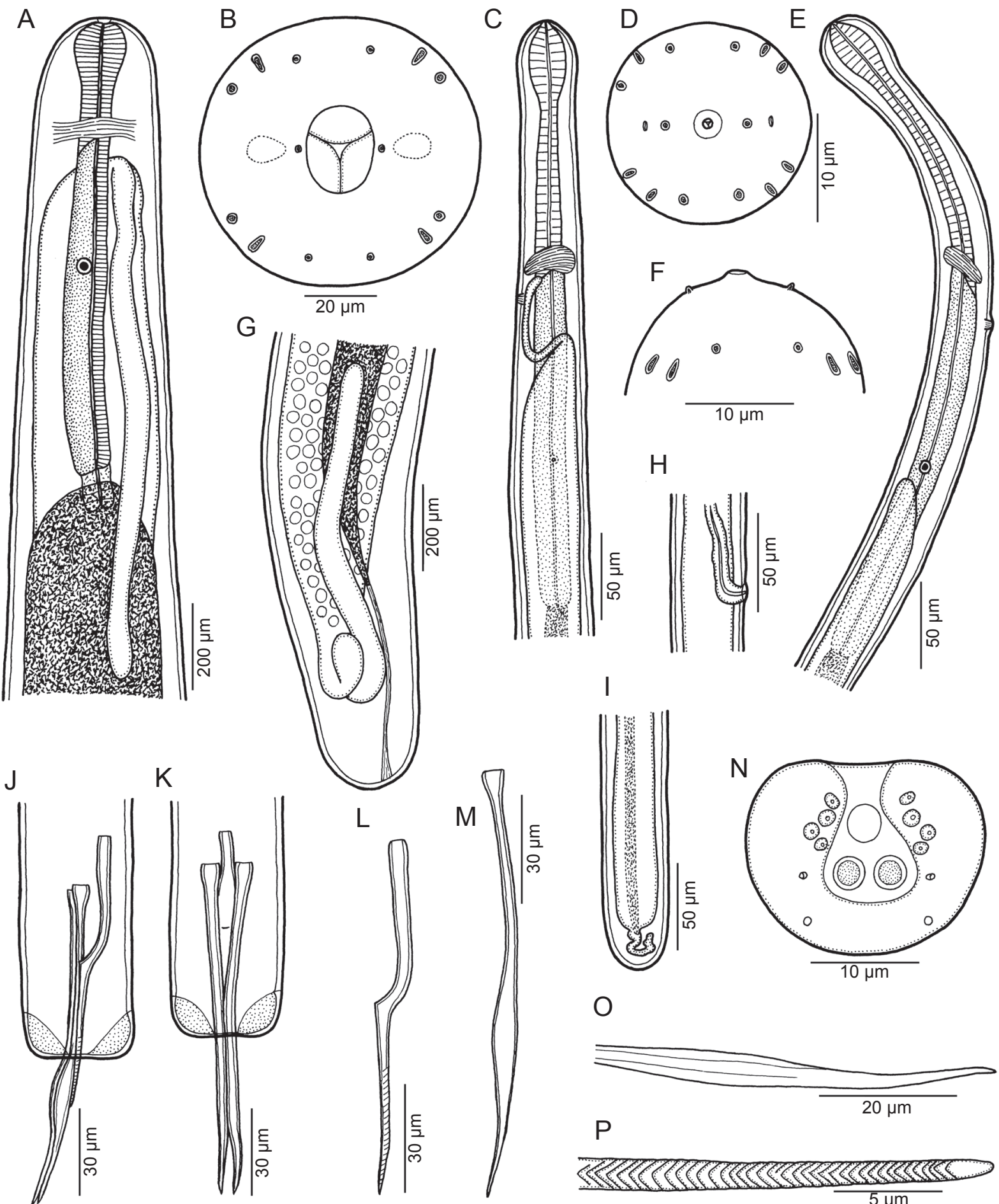

$\mathrm{K}$

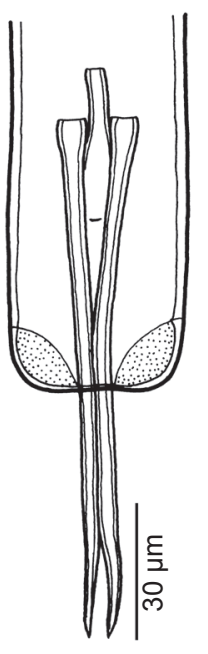

$\mathrm{L}$
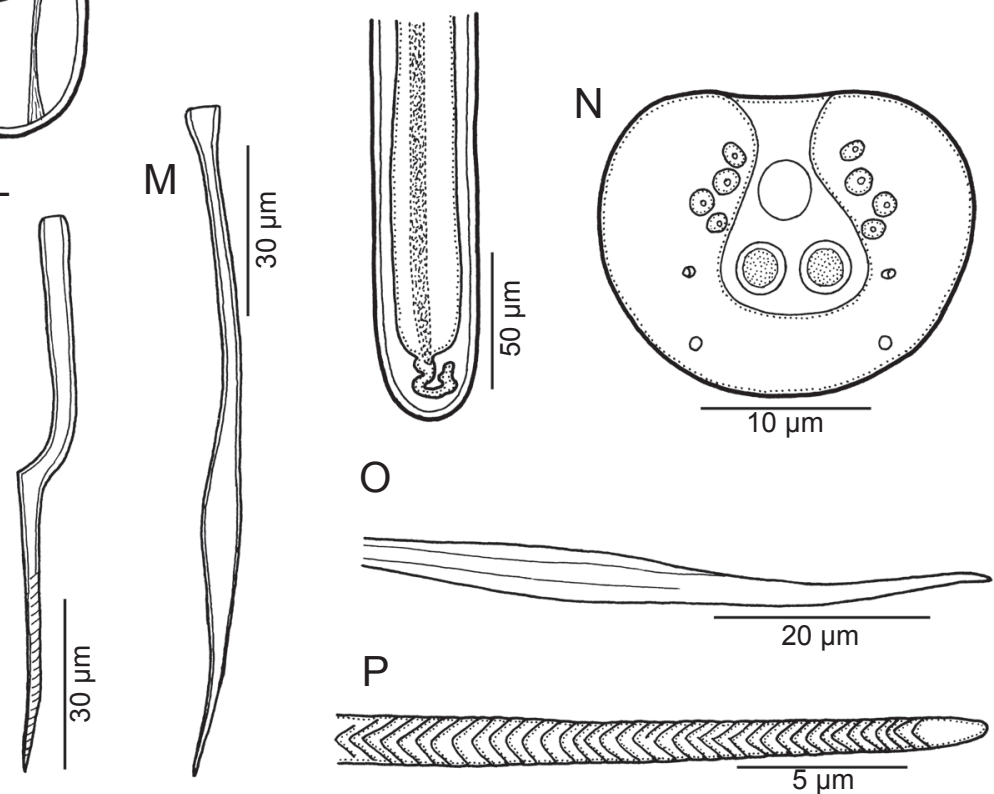

Fig. 5. Philometra latispicula sp. n. from Lutjanus griseus. A - anterior end of subgravid female, lateral view; $\mathbf{B}$ - cephalic end of subgravid female, apical view; $\mathbf{C}$ - anterior end of mature female, lateral view; $\mathbf{D}$ - cephalic end of male, apical view; $\mathbf{E}$ - anterior end of male, lateral view; $\mathbf{F}$ - cephalic end of male, dorsoventral view; $\mathbf{G}$ - posterior end of subgravid female, lateral view; $\mathbf{H}$ - vulva of mature female, lateral view; $\mathbf{I}$ - posterior end of mature female, lateral view; $\mathbf{J}, \mathbf{K}$ - caudal end of male, lateral and ventral views; $\mathbf{L}$ - gubernaculum, lateral view; $\mathbf{M}$ - spicule, lateral view; $\mathbf{N}$ - caudal end of male, apical view; $\mathbf{O}$ - distal part of spicule, lateral view; $\mathbf{P}$ - distal part of gubernaculum, dorsal view.

to lateral edges of gubernaculum, serrations ending just proximally to smooth apex of gubernaculum (Figs. 5J,L,P, $6 \mathrm{C}, \mathrm{E}, 7 \mathrm{~A}-\mathrm{E}, \mathrm{G})$. Length ratio of gubernaculum and larger spicule $1: 1.14-2.37(1: 1.18)[1: 1.56]$. Spicules and gubernaculum well sclerotised; spicules and gubernaculum yellowish except anterior part of gubernaculum colourless. 


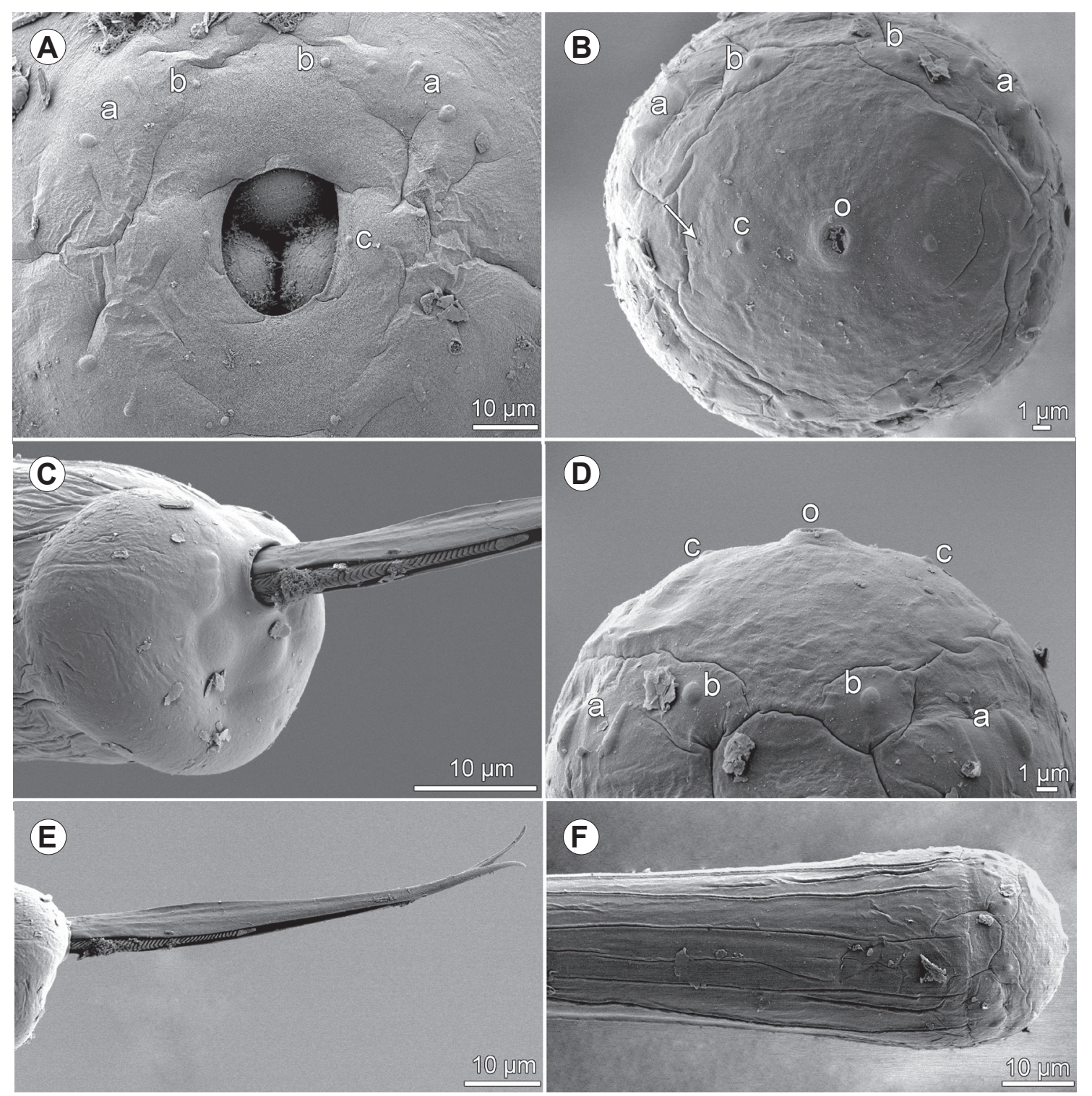

Fig. 6. Philometra latispicula sp. n. from Lutjanus griseus, scanning electron micrographs. A - cephalic end of subgravid female, apical view; $\mathbf{B}$ - cephalic end of male, apical view (arrow indicates amphid); $\mathbf{C}$ - caudal end of male, lateral view; $\mathbf{D}$ - cephalic end of male, dorsoventral view; $\mathbf{E}$ - protruded distal parts of spicules and gubernaculum, lateral view; $\mathbf{F}$ - typical shape of male cephalic end, dorsoventral view. Abbreviations: a - submedian pair of cephalic papillae of external circle; $\mathrm{b}$ - submedian cephalic papilla of internal circle; $\mathrm{c}$ - lateral cephalic papilla of inner circle; $\mathrm{o}$ - oral aperture.

Subgravid female (12 ovigerous specimens; measurements of allotype in parentheses): Body of fixed specimens brown-coloured, with rounded ends. Posterior part of body narrower than anterior part; maximum width in region just posterior to oesophagus. Cuticle smooth. Body length 41-90 (90) mm, maximum width 422-680 (680), maximum width/body length ratio $1: 88-132(1: 132)$. Width of cephalic end 218-422 (422). Cephalic papillae small, indistinct when viewed laterally. Oral aperture oval, surrounded by small cephalic papillae arranged in 2 circles and slightly outlines amphids; inner circle of papillae consisting of 4 submedian and 2 lateral single papillae, whereas outer circle formed by 4 submedian pairs of papillae, each composed of 1 short and 1 elongate papilla (Figs. 5B, 6A). Oesophagus including anterior bulbous inflation 0.97-1.27 (1.20) mm long, comprising $1.3-2.6(1.3) \%$ of body length; anterior inflation $122-150$ (150) long and 109-136 (136) wide; maximum width of posterior part of oesophagus including gland 95-122 (122). Oesophageal gland well developed, opening into oesophagus just posterior to nerve ring, with large cell nucleus (Fig. 5A). Nerve ring and oesophageal nucleus 258-340 (313) and 517-694 (694), respectively, from anterior extremity. Ventriculus small, 21-45 (21) long, 81-120 (105) wide. Posterior end of intestine attached ventrally by short ligament to body wall near caudal end 

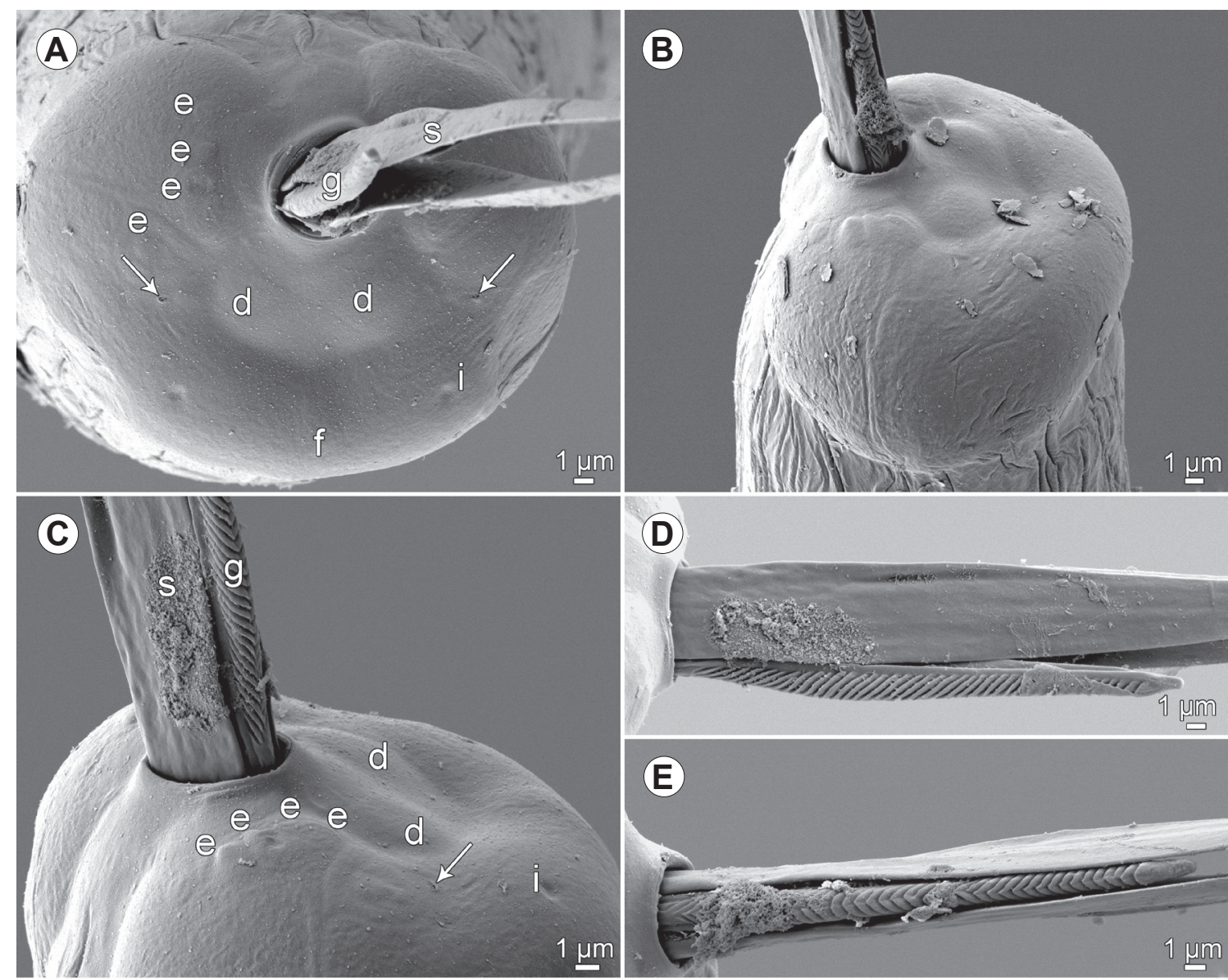

(E)
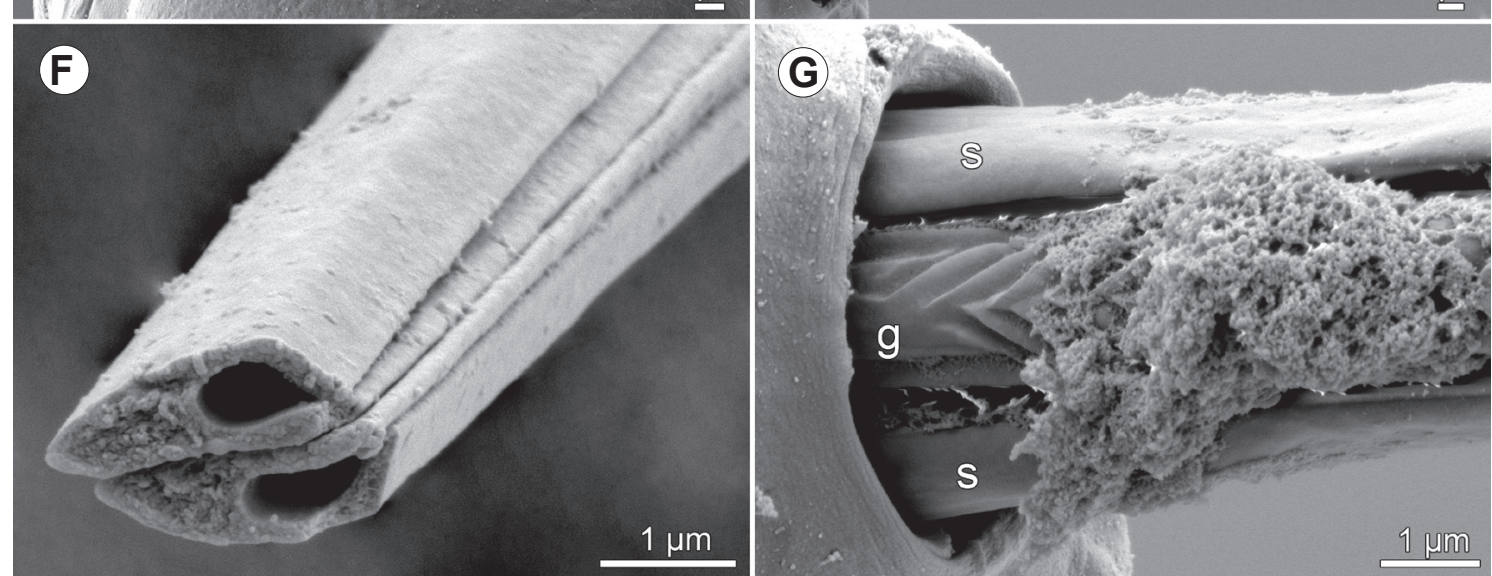

Fig. 7. Philometra latispicula sp. n. from Lutjanus griseus, scanning electron micrographs of male. A, B - caudal end, apical and subapical views (arrows indicate phasmids); $\mathbf{C}$ - caudal end, sublateral view (arrow indicates phasmid); $\mathbf{D}, \mathbf{E}-$ protruded distal parts of spicules and gubernaculum, lateral and dorsal views; $\mathbf{F}$ - broken spicules, apical view; $\mathbf{G}$ - detail of most proximal lamellar structure of gubernaculum, dorsal view. Abbreviations: $\mathrm{d}$ - postcloacal caudal papilla; e - adcloacal papilla; $\mathrm{f}$ - caudal mound; $\mathrm{g}$ - gubernaculum; $\mathrm{i}$ - minute caudal depression; $\mathrm{s}$ - spicule.

(Fig. 5G); length of ligament 367-544 (381). Vulva and anus absent. Ovaries reflexed near body ends (Fig. 5A,G). Uterus filled with spherical eggs. Posterior end of female rounded, 204-272 (218) wide, without caudal projections (Fig. 5G).

Nongravid female (2 mature specimens): Body length 2.63-2.65 mm, maximum width 42-45; maximum width/ length ratio $1: 58-63$. Width of anterior end 24-39, of narrowed part just posterior to anterior end 21, of posterior end 24-33. Entire oesophagus 390-429 long and 24-27 wide. Anterior oesophageal bulb 24-39 long, 18-24 wide. Nerve ring and oesophageal nucleus $150-165$ and 270, respectively, from anterior extremity (Fig. 5C). Vulva and incompletely developed vagina present, former situated 
$1.66-1.81 \mathrm{~mm}$ from anterior extremity (at $63-68 \%$ of body length) (Fig. 5H). Uterus empty. Caudal end rounded (Fig. 5I).

Type host: Grey snapper Lutjanus griseus (Linnaeus) (Perciformes: Lutjanidae), SL $309 \mathrm{~mm}$ (host of holotype) and $335 \mathrm{~mm}$.

Site of infection: Gonad (ovary and testis).

Type locality: Gulf of Mexico; August 7, 2013 (28¹9.34'N, $\left.84^{\circ} 10.28^{\prime} \mathrm{W}\right)$.

Other locality: Gulf of Mexico; August 7, 2013 $\left(28^{\circ} 15.89^{\prime} \mathrm{N}, 84^{\circ} 7.30^{\prime} \mathrm{W}\right)$

Prevalence and intensity: 6\% (2 infected out of 34 examined; female hosts $20 \%(2 / 10)$; male hosts $0 \%(0 / 13)$; juvenile hosts $0 \%(0 / 11)) ; 9$ and 14 nematodes per fish.

Deposition of type specimens: Holotype (male), allotype (female) and 11 paratypes (10 males, 1 female) in the U.S. National Parasite Collection, Beltsville, Maryland, USA (USNPC Nos. 107909-107911); 44 paratypes (32 males, 12 females) in the Helminthological Collection of the Institute of Parasitology, Biology Centre of the Academy of Sciences of the Czech Republic, České Budějovice (IPCAS N-1036).

Etymology: The specific name latispicula (latus = broad; spicula $=$ spicule) relates to a characteristic feature of this nematode, i.e. the presence of conspicuously ventrally delated spicules.

Remarks. Philometra latispicula sp. n. differs from all nominal gonad-infecting species of Philometra with described males in possessing spicules that are conspicuously ventrally distended at their posterior halves. In addition, $P$. latispicula can be distinguished from the majority of these species by the length of spicules. Considering the species possessing lamellar structures or serrations without a distinct dorsal protuberance on the distal tip of the gubernaculum, as in $P$. latispicula, the length of spicules of the new species is similar only to those of $P$. charlestonensis Moravec, de Buron, Baker et González-Solís, 2008 (spicules 132-141 $\mu \mathrm{m}), P$. genypteri Moravec, Chávez et Oliva, 2011 (126-135 $\mu \mathrm{m})$, P. hyporthodi $(135-138 \mu \mathrm{m})$ and $P$. sciaenae Yamaguti, $1941(96-138 \mu \mathrm{m})$. However, these species differ in the number and arrangement of genital papillae and some other features and in their respective host families (Ophiidae, Sciaenidae and Serranidae vs Lutjanidae). Additionally, $P$. genypteri and $P$. sciaenae differ from $P$. latispicula in geographical distribution (Pacific vs Atlantic Oceans).

Since gravid females of $P$. latispicula remain undescribed, no morphological characteristic can be used to distinguish it from the seven gonad-infecting species of Philometra with unknown males. However, it is possible to distinguish the new species from $P$. inimici, $P$. managatuwo, $P$. neptomeni, $P$. otolithi, $P$. sebastisci, $P$. serranellicabrillae and $P$. zabidii on the basis of fish host families (Lutjanidae vs Centrolophidae, Ephippidae, Platycephalidae, Sciaenidae, Sebastidae, Serranidae, Synanceiidae or Stromateidae) and geographical distribution (western Atlantic vs Indo-Pacific or Mediterranean).
Philometra synagridis sp. $\mathrm{n}$.

Figs. 8, 9

Male (5 specimens; measurements of holotype in parentheses): Body filiform, whitish, 4.37-4.69 (4.41) mm long, maximum width at posterior half of body 42-60 (51), with markedly slender anterior end; anterior part of body somewhat narrowed just posterior to cephalic end (Fig. 8A); body width at this narrowed part 18-30 (21). Maximum width/body length $1: 78-106(1: 86)$; width of cephalic end 21-27 (24), that of posterior end 30-36 (30). Cuticle smooth. Cephalic end rounded.

Oral aperture oval, surrounded by 14 cephalic papillae arranged in 2 circles: outer circle formed by 4 submedian pairs of papillae; inner circle by 4 submedian and 2 lateral single papillae; small lateral amphids just posterior to lateral papillae of internal circle (Figs. 8B, 9A,B). Oesophagus 513-603 (576) long, forming 12-14 (13)\% of body length, somewhat inflated at anterior end; posterior part of muscular oesophagus overlapped by well developed oesophageal gland 18-24 (21) wide with large cell nucleus in middle. Oesophageal nucleus and nerve ring 276-399 (399) and 165-216 (207), respectively, from anterior extremity. Excretory pore 213-273 (258) from anterior end.

Testis overlaps posterior part of oesophageal gland, usually reaching anteriorly to about oesophageal nucleus (Fig. 8A). Posterior end of body blunt; broad caudal mound formed by a pair of lateral lobes, each lobe comprising a set of 3 distinct lobules, dorsolateral lobules within each set well separated from lateral lobules, lobes well separated dorsally and separated by and nearly abbuting cloacal aperture ventrally (Figs. 8G, 9C-E). Genital papillae very flat, difficult to observe, forming groups of 4 on each side of cloacal aperture; pair of small phasmids situated near inner border of lateral lobules of caudal mound (Figs. 8G, 9D). Spicules slightly subequal in length, slender, needlelike; proximal ends somewhat expanded, less sclerotised than posterior parts of spicules, distal tips sharply pointed (Figs. 8E,F, 9C,E-G); length of larger spicule 192-219 (219), of smaller spicule 186-213 (210); longer spicule representing 4-5 (5)\% of body length.

Gubernaculum narrow, 87-90 (90) long, with anterior portion somewhat dorsally bent; length of bent part 10-11 (10), representing 10-12 (11)\% of entire gubernaculum length. Distal part of gubernaculum rounded, each dorsolateral margin with a rounded transversely striated ridge. These ridges separated along their entire length by a smooth depressed distally tapering field. Depressed field extending past most distally situated dorsolateral striae but ending well forward of gubernaculum apex (Figs. 8C,D,F, 9C,F,G). Length ratio of gubernaculum and larger spicule $1: 2.21-2.43$ (1:2.43). Spicules yellowish, gubernaculum colourless.

Female: Unknown.

Type host: Lane snapper Lutjanus synagris (Linnaeus) (Perciformes: Lutjanidae), SL $209 \mathrm{~mm}$ (host of holotype) and 
A

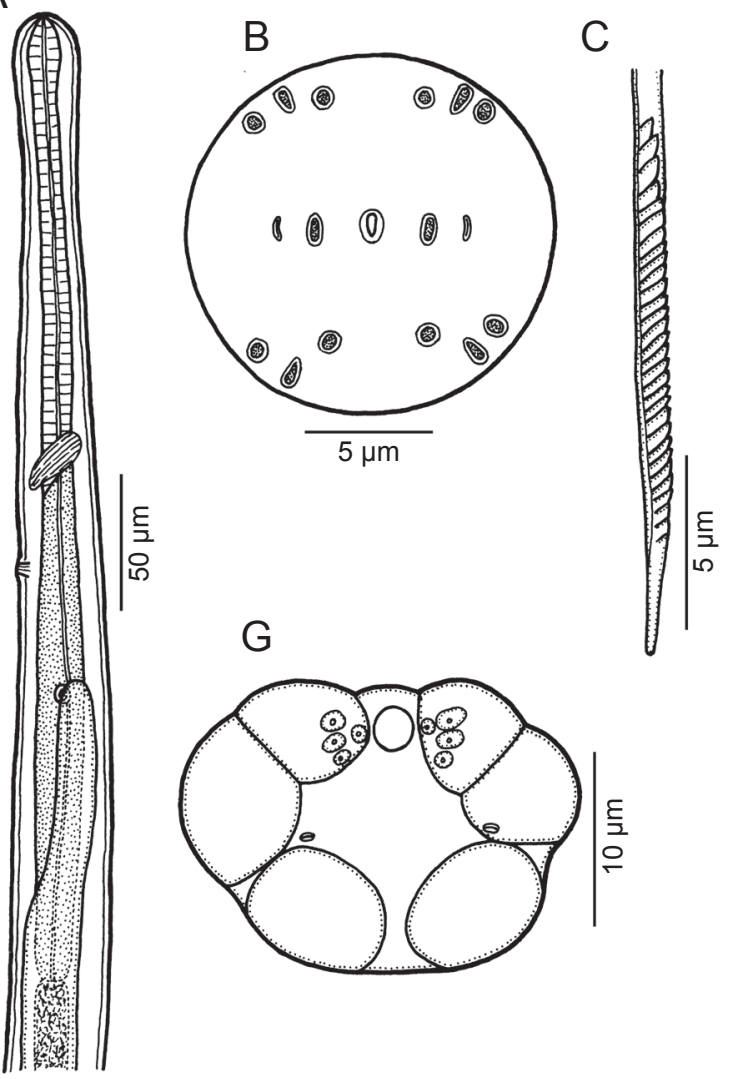

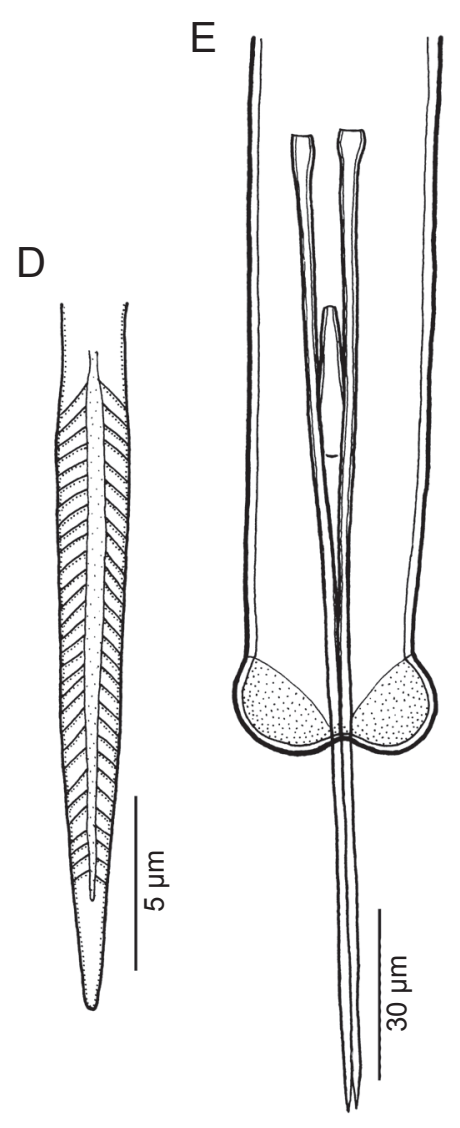

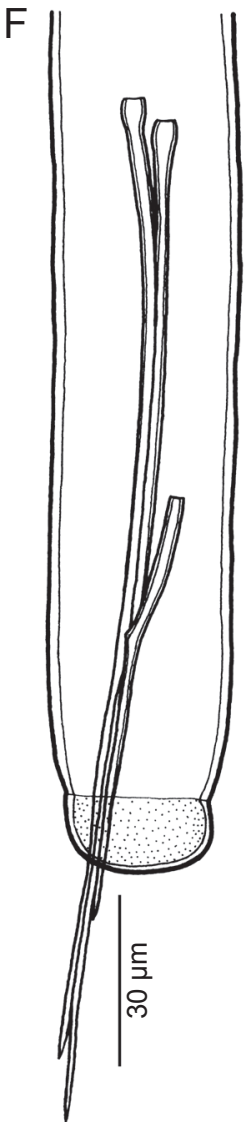

Fig. 8. Male of Philometra synagridis sp. n. from Lutjanus synagris. A - anterior end of body, lateral view; B - cephalic end, apical view; C, D - distal part of gubernaculum, lateral and dorsal views; E, F - posterior end, ventral and lateral views; $\mathbf{G}$ - caudal end, apical view.

$255 \mathrm{~mm}$.

Site of infection: Gonad (ovary).

Type locality: Gulf of Mexico; 28 August 2013 (28²5.13'N, $\left.82^{\circ} 55.28^{\prime} \mathrm{W}\right)$.

Prevalence and intensity: 2 fish infected out of 8 examined (female hosts 2/3 examined; male hosts $0 / 5$ ); 14 and 26 (mean 20) nematodes.

Deposition of type specimens: Holotype (male) in the U.S. National Parasite Collection, Beltsville, Maryland, USA (USNPC No. 107912); 1 paratype (male) in the Helminthological Collection of the Institute of Parasitology, Biology Centre of the Academy of Sciences of the Czech Republic, České Budějovice (IPCAS N-1037).

Etymology: The name of this species is derived from the specific name of its fish host.

Remarks. Considering gonad-infecting species of Philometra, by the length of spicules $P$. synagridis sp. n. resembles only $P$. cyanopodi Moravec et Jus-

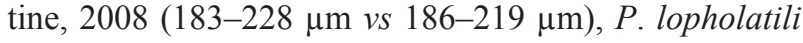
$(165-189 \mu \mathrm{m})$ and P. tenuicauda Moravec et Justine, 2009 $(245-248 \mu \mathrm{m})$; in other species with described males, the spicules are shorter than $160 \mu \mathrm{m}$ or longer than $250 \mu \mathrm{m}$. However, $P$. cyanopodi differs in having a distinctly longer gubernaculum (129-162 $\mu \mathrm{m} v s$ 87-90 $\mu \mathrm{m})$ and a shorter body length (2.72-3.59 $\mathrm{mm} v s$ 4.37-4.69 $\mathrm{mm})$, $P$. lopholatili in a longer gubernaculum $(114-126 \mu \mathrm{m})$, proportion of the anterior bent part of gubernaculum to the entire gubernaculum length (36-43\% vs 10-12\%) and a shorter male body $(3.26-3.86 \mathrm{~mm})$, and P. tenuicauda in possessing a distinct dorsal protuberance on the distal end of the gubernaculum, which is absent in the new species. Moreover, all these three species differ in the fish host family (Malacanthidae, Serranidae and Tetraodontidae vs Lutjanidae) and P. cyanopodi and P. tenuicauda also in the geographical distribution (South Pacific vs North Atlantic) (Moravec and Justine 2008, 2009, 2011, Moravec and Bakenhaster 2013).

Moreover, in the structure of the distal part of gubernaculum, i.e. with a ridge of striae along each dorsolateral margin separated by a smooth field, $P$. synagridis is similar only to $P$. brevicollis and P. longispicula sp. n., both parasites of Lutjanus spp. in New Caledonian waters and in the Gulf of Mexico, respectively, from which the new species can be distinguished by the length of spicules, structure of the caudal end and some other morphological features.

Since the female of $P$. synagridis remains unknown, the above-mentioned seven gonad-infecting species of 

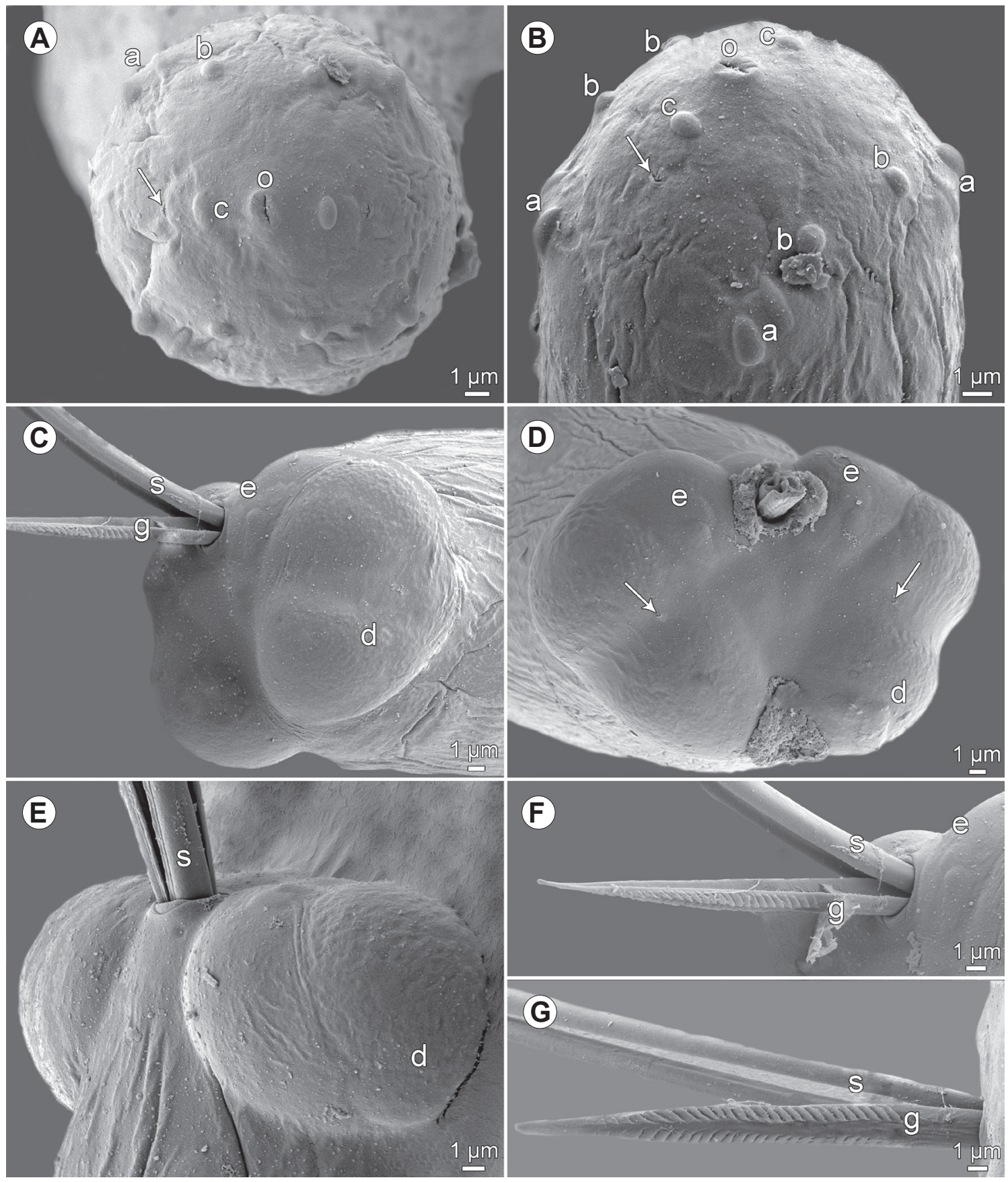

Fig. 9. Philometra synagridis sp. n. from Lutjanus synagris, scanning electron micrographs of male. A, B - cephalic end, apical and sublateral views (arrows indicate amphids); $\mathbf{C}-\mathbf{E}$ - caudal end, sublateral, apical and subventral views, respectively (arrows indicate phasmids); F, G - distal part of gubernaculum, lateral and dorsal views. Abbreviations: a - submedian pair of cephalic papillae of external circle; $\mathrm{b}$ - submedian cephalic papilla of internal circle; $\mathrm{c}$ - lateral cephalic papilla of internal circle; $\mathrm{d}$ - caudal mound; $\mathrm{e}$ - group of adcloacal caudal papillae; $\mathrm{g}$ - gubernaculum; $\mathrm{o}$ - oral aperture; $\mathrm{s}$ - spicule.

Philometra known only by their females can be distinguished on the basis of fish host families (Lutjanidae vs Centrolophidae, Ephippidae, Platycephalidae, Sciaenidae, Sebastidae, Serranidae, Synanceiidae or Stromateidae) and geographical distribution (western Atlantic vs IndoPacific or Mediterranean).

\section{DISCUSSION}

Snappers (Lutjanus spp.) have already been recorded as hosts of gonad-infecting species of Philometra. Linton (1907) and Rees (1970) reported Ichthyonema (= Philometra) sp. or Philometra spp. from the gonads of Lutjanus synagris and Lutjanus spp. from Bermuda, which were considered by Moravec et al. (1988) to be prob- 
ably Philometra lateolabracis (Yamaguti, 1935). From the region of the western Atlantic, P. lateolabracis was also reported by Martínez and Ventosa (1982) from the gonads of L. synagris off Cuba. However, with respect to the redescription of $P$. lateolabracis by Quiazon et al. (2008), Moravec (2008) considered all these nematodes to apparently belong to other species and recommended to designate them as Philometra sp. Santos Cavalcanti et al. (2010) reported Philometra sp. from the gonads of L. synagris from off the Brazilian Atlantic coast. It is highly probable that all these previously reported gonadinfecting philometrids from L. synagris belonged in fact to $P$. synagridis described in this paper. Two other gonad-infecting species of Philometra, $P$. brevicollis and P. mira Moravec et Justine, 2011, were reported from New Caledonian waters (Moravec and Justine 2011) and Philometra sp. from the ovary of Lutjanus carponotatus (Richardson) off the northern coast of Australia (Moravec and Diggles 2014).

In addition to gonad-infecting species of Philometra, two other philometrids, P. brevispicula Moravec et Bakenhaster, 2010 (a parasite of mouth tissues) and Dentiphilometra lutjani Gonzáles-Solís, Moravec et Tuz Paredes, 2007 (a parasite of body musculature), were described from Lutjanus griseus in Florida Bay, USA (Moravec and Bakenhaster 2010) and off the Caribbean coast of Mexico (González-Solís et al. 2007), respectively. Single fish species have previously been reported to host two or more species of Philometra when, as adult females, the nematode species have different infection sites (e.g. Moravec et al. 2010), so the records of both P. brevispicula and $P$. latispicula infecting $L$. griseus are not surprising.

A remarkable finding of this study is the record of three morphologically well-distinguished species of Philometra from the gonads of different species of congeneric hosts in the same region. This indicates a high degree of host specificity of gonad-infecting philometrids. With continued discoveries of new species of Philometra in lutjanid hosts from the world oceans, these host-parasite pairings increasingly represent components of an appealing model for the study of speciation, co-evolution and host switching. While the host species in the present study range substantially in depth preferences from estuarine and coastal waters ( $L$. griseus is typically found at $<50 \mathrm{~m}$ depth) to areas far off shore (L. vivanus does not occur in waters shallower than about $90 \mathrm{~m}$ ), all four occur together over reefs from around $90-180 \mathrm{~m}$ in depth (Froese and Pauly 2014), where presumably they are exposed to the same suite of potentially infected intermediate hosts. According to Miller and Cribb (2007) and Gold et al. (2011), mitochondrial DNA sequence data strongly support the hypothesis that all western Atlantic lutjanids are evolutionarily derived from Indo-Pacific species that dispersed from the eastern Pacific into the western Atlantic through the Panamanian Gateway during the early Miocene (circa 20 mya). Probably they carried with them some progenitors of extant lutjanid-infecting philometrids. The Indo-
Pacific lutjanid L. vitta is reported to host in its gonad both $P$. brevicollis (which shares unusual morphological traits of the gubernaculum with $P$. brevispicula and $P$. synagridis) and $P$. mira (see Moravec and Justine 2011). However, as is the case with $P$. longispicula infecting L. vivanus in the present study, Moravec and Justine (2011) found only males of the latter species and in small numbers. Based on their findings, these authors hypothesised that $L$. vitta might be a paradefinitive host for $P$. mira, and the same may be true for L. vivanus hosting $P$. longispicula. Nevertheless, there may be host-parasite co-evolutionary significance in the genetic similarity between L. vivanus and the demonstrated definitive host of P. longispicula, L. campechanus. Gold et al. (2011) found that $L$. campechanus and $L$. vivanus are much more closely related to each other (diverging 1.8-3.8 mya) than they are to L. synagris or L. griseus (diverging approximately 10 and 20 mya, respectively). Likely, more as yet undescribed species of gonad-infecting Philometra exist in lutjanid hosts, and continued taxonomic study coupled with phylogenetic analyses could produce results of broad interest.

Acknowledgements. Bob McMichael, Theresa (Kanaska) Warner, Gregg Onorato, Tim MacDonald and many other members of the FWC/FWRI Fisheries Independent Monitoring Program (FIM) provided access to specimens, allowed us to participate in research cruises, and shared their data. Chris Gardinal (FWRI) led spear fishing sampling trips. Amy Wallace (USF) provided critical field support, Clark Gray and Lauren Partridge (both FWRI) conducted shipboard sampling on offshore research cruises, and along with Adam Richardson, Theresa Cody, Maki Tabuchi, Yasu Kiryu, Catalina Brown and Melissa Broderick (all FWRI) assisted in laboratory processing of specimens. Craig Harmack (FWRI) generated the map used for Figure 1. Authors' thanks are also due to the staff of the Laboratory of Electron Microscopy, Institute of Parasitology, Biology Centre of the AS CR, České Budějovice for their technical assistance, and to Blanka Škoríková of the same Institute for help with illustrations. This study was partly supported by the Czech Science Foundation (grant No. P505/12/G112) and the Institute of Parasitology, BC AS CR (institutional support RVO:60077344). Sampling of hosts and parasites was funded collectively by State of Florida saltwater recreational fishing license revenues, the Department of Interior, U.S. Fish and Wildlife Service, Federal Aid for Sportfish Restoration Grants F-72 and F-43, CONACyT Mexico Sabbatical Grant 2012-2013 (application number 186868), and by the National Marine Fisheries Service, Southeast Regional Office through three grants, the first (NA11NMF4720151) to Steve Murowski (USF) for the project "Systematic Survey of Fish Diseases in the Gulf of Mexico", the second (NA12NMF454008) to Chris Stallings (USF), Bob McMichael (FWRI) and Ted Switzer (FWRI) for the project "Combining Fishery-Independent and Fishery-Dependend Methods: a Pilot Study on a Hybrid Approach to Sampling Reef Fishes", and the third (NA06NMF4350009) to FWRI for the project "Florida/ NMFS Cooperative Southeast Area Monitoring and Assessment Program". The views and conclusions contained in this document are those of the authors and should not be interpreted as representing the opinions or policies of the U.S. government. 
Bakenhaster M.B., Lowerrw-Barbieri S., Kiryu Y., WalTERS S., FAJER-Ávila E.J. 2014: Philometra floridensis (Nematoda: Philometridae) damages ovarian tissue without reducing host fecundity. Dis. Aquat. Org. 108: 227-239.

Cárdenas M.Q., Moravec F., Kohn A. 2009: First record of Philometra katsuwoni (Nematoda, Philometridae), a parasite of skipjack tuna Katsuwonus pelamis (Perciformes, Scombridae), off South American Atlantic coast. Biota Neotrop. 9: 263-266.

Froese R., Pauly D. (Eds.) 2014: FishBase. World Wide Web electronic publication, http://www.fishbase.org, 01/2014.

Gold J.R., Voelker G., Renshaw M.A. 2011: Phylogenetic relationships of tropical western Atlantic snappers in subfamily Lutjaninae (Lutjanidae: Perciformes) inferred from mitochondrial DNA sequences. Biol. J. Linn. Soc. 102: 915-929.

González-Solís D., Moravec F., Tuz Paredes V.M. 2007 : A new species of Dentiphilometra (Nematoda: Philometridae) from the musculature of the gray snapper Lutjanus griseus (Osteichthyes) off the Caribbean coast of Mexico. J. Parasitol. 93: 1132-1135.

Linton E. 1907: Notes on parasites of Bermuda fishes. Proc. U.S. Nat. Mus. 33: 85-126.

Martínez J.J., Ventosa L. 1982: Philometra lateolabracis (Nematoda: Philometridae), parásito de la biajaiba (Lutjanus synagris) (Osteichthyes: Lutjanidae) de Cuba. Poeyana 248: $1-6$.

Miller T.L., CribB T.H. 2007: Phylogenetic relationships of some common Indo-Pacific snappers (Perciformes: Lutjanidae) based on mitochondrial DNA sequences, with comments on the taxonomic position of the Caesioninae. Mol. Phylogen. Evol. 44: $450-460$

Moravec F. 1969: [Nematodes of fishes in Czechoslovakia and life cycles of some species. Parts I, II.] Ph.D. thesis, Institute of Parasitology, Czechoslovak Academy of Sciences, Prague, 193 pp. +96 Plts. (In Czech.)

Moravec F. 2008: Systematic status of Philometra jordanoi (López-Neyra, 1951) and some other congeneric species previously identified as Philometra lateolabracis (Yamaguti, 1935) (Nematoda: Philometridae). Folia Parasitol. 55: 159-160.

Moravec F., Ali A.H. 2013: Philometra johnii sp. nov. (Nematoda, Philometridae), a new gonad-infecting philometrid from the sin croaker Johnius dussumieri (Cuvier) (Perciformes, Sciaenidae) from marine waters of Iraq. Acta Parasitol. 58: 263-268.

Moravec F., Ali A.H. 2014: Additional observations on Philometra spp. (Nematoda: Philometridae) in marine fishes off Iraq, with the description of two new species. Syst. Parasitol. 87: 259-271.

Moravec F., Bakenhaster M. 2010: Philometrid nematodes infecting fishes from the Everglades National Park, Florida, USA, with description of two new species. Folia Parasitol. 57: 213-222.

Moravec F., Bakenhaster M. 2013: Two new gonad-infecting philometrids (Nematoda: Philometridae) from the yellowedge grouper Hyporthodus flavolimbatus (Serranidae) and the great northern tilefish Lopholatilus chamaeleonticeps (Malacanthidae) in the northern Gulf of Mexico. Syst. Parasitol. 86: 113123.

Moravec F., Bakenhaster M., De Buron I. 2013: A new gonad-infecting species of Philometra (Nematoda: Philometridae) from the Atlantic Spanish mackerel Scomberomorus maculatus (Scombridae) off the Atlantic coast of Florida and South Carolina. J. Parasitol. 99: 290-296.
Moravec F., Bakenhaster M., Fajer-Ávila E.J. 2010: New philometrids (Nematoda, Philometridae) from head tissues of two serranid fishes (Epinephelus morio and Mycteroperca microlepis) off Florida, northern Gulf of Mexico. Acta Parasitol. 55: 359-368.

Moravec F., Diggles B.K. 2014: Philometrid nematodes (Philometridae) from marine fishes off the northern coast of Australia, including three new species. Folia Parasitol. 61: 35-54.

Moravec F., Justine J.-L. 2008: Some philometrid nematodes (Philometridae), including four new species of Philometra, from marine fishes off New Caledonia. Acta Parasitol. 53: 369-381.

Moravec F., Justine J.-L. 2009: New data on dracunculoid nematodes from fishes off New Caledonia, including four new species of Philometra (Philometridae) and Ichthyofilaria (Guyanemidae). Folia Parasitol. 56: 129-142.

Moravec F. Justine J.-L. 2011: Two new gonad-infecting Philometra species (Nematoda: Philometridae) from the marine fish Lutjanus vitta (Perciformes: Lutjanidae) off New Caledonia. Folia Parasitol. 58: 302-310.

Moravec F., Justine J.-L. 2014: Philometrids (Nematoda: Philometridae) in carangid and serranid fishes off New Caledonia, including three new species. Parasite 21: 21.

Moravec F., Orecchia P., Paggi L. 1988: Three interesting nematodes from the fish Parupeneus indicus (Mullidae, Perciformes) of the Indian Ocean, including a new species, Ascarophis parupenei sp. n. (Habronematoidea). Folia Parasitol. 35: 47-57.

Moravec F., Vidal-Martínez V.M., Aguirre-Macedo L. 1995: Philometra margolisi n. sp. (Nematoda: Philometridae) from the gonads of the red grouper, Epinephelus morio (Pisces: Serranidae), in Mexico. Can. J. Fish. Aquat. Sci. 52 (Suppl. 1): $161-165$.

Moravec F., Vidal-Martínez V.M., Vargas-Vázquez J., Vivas-Rodríguez C., González-Solís D., MendozaFranco E., Simá-Alvarez R., Güemez-Ricalde J. 1997: Helminth parasites of Epinephelus morio (Pisces: Serranidae) of the Yucatan Peninsula, southeastern Mexico. Folia Parasitol. 44: 255-266.

Petter A.-J., Baudin-Laurencin F. 1986: Deux espèces du genre Philometra (Nematoda, Dracunculoidea) parasites de thons. Bull. Mus. Nat. Hist. Nat., Paris, 4e Sér., Sect. A, 8: 769-775.

Quiazon K.M.A., Yoshinaga T. 2013: Gonad-infecting philometrid Philometra philippinensis sp. nov. (Nematoda, Philometridae) from the bigeye barracuda Sphyraena forsteri Cuvier (Sphyraenidae) off Mariveles, Bataan Province, Philippine Archipelago. Acta Parasitol. 58: 504-514.

Quiazon K.M.A., Yoshinaga T., Ogawa K. 2008: Taxonomical study into two new species of Philometra (Nematoda: Philometridae) previously identified as Philometra lateolabracis (Yamaguti, 1935). Folia Parasitol. 55: 29-41.

ReEs G. 1970: Some helminth parasites of fishes of Bermuda and an account of the attachment organ of Alcicornis carangis MacCallum, 1917 (Digenea: Bucephalidae). Parasitology 60: 195-221.

Santos Cavalcanti E.T., Takemoto R.M., Alves L.C., Chellappa S. 2010: First record of endoparasite Philometra sp. (Nematoda: Philometridae) in lane snapper Lutjanus synagris from the coast of Rio Grande do Norte, Brazil. Mar. Biodiv. Rec. 3: 1-4. 